\title{
Shear-assisted water-fluxed melting and AFC processes in the foreland of the Early Paleozoic Famatinian orogen: petrogenesis of leucogranites and pegmatites from the Sierras de Córdoba, Argentina
}

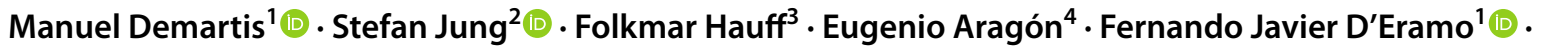

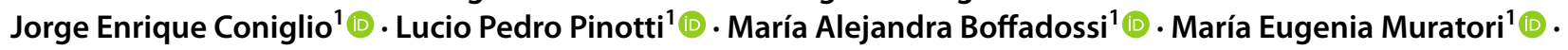 \\ Joaquín Coniglio ${ }^{1}$ (1)
}

Received: 4 February 2020 / Accepted: 20 November 2020

(c) Geologische Vereinigung e.V. (GV) 2021

\begin{abstract}
In the Comechingones pegmatitic field, central Argentina, leucogranite and pegmatite bodies crop out in a relatively narrow $(25 \times 10 \mathrm{~km})$ belt, and were emplaced synkinematically with the main deformational event of the crustal-scale Guacha Corral shear zone during the Early Ordovician $(\sim 475 \mathrm{Ma})$. These leucogranites and pegmatites are geochemically evolved rocks with high silica and alkalis, low $\mathrm{Fe}_{2} \mathrm{O}_{3}, \mathrm{MgO}, \mathrm{TiO}_{2}$ and $\mathrm{CaO}$, and high ASI values. The leucogranites display quite variable $\mathrm{Sr}$ and $\mathrm{Nd}$ isotope compositions (initial ${ }^{87} \mathrm{Sr} /{ }^{86} \mathrm{Sr}$ ratios from 0.7048 to 0.7170 , and $\varepsilon_{\mathrm{Nd}}$ values from +2.0 to -3.1 ), some of which do not overlap with almost any other pre-Famatinian rock from the Sierras de Córdoba. The major and trace element geochemistry and the particular $\mathrm{Sr}$ and $\mathrm{Nd}$ isotope compositions of the leucogranites are here explained by the following processes: (1) water-fluxed partial melting of amphibolites at relatively low $\mathrm{P}-\mathrm{T}$ conditions generating currently unexposed granodioritic melts with unradiogenic ${ }^{87} \mathrm{Sr} /{ }^{86} \mathrm{Sr}$ ratios and radiogenic $\varepsilon_{\mathrm{Nd}}$ values; (2) fractionation of mostly plagioclase and monazite leading to compositions close to the leucogranite melts; and (3) assimilation of metasedimentary rocks with crustal isotopic signatures, modelled by assimilation and fractional crystallization processes. The major, trace and isotope compositions of the pegmatites suggest a derivation from partial melting of the same metasedimentary protoliths of the Sierras de Córdoba that were assimilated by leucogranite melts. We propose a feedback relationship among deformation, anatexis, magma evolution and mass transfer in the context of such a crustal-scale shear zone in the foreland of the Famatinian orogen.
\end{abstract}

Keywords Leucogranite $\cdot$ Granitic pegmatite $\cdot$ Sr nd isotopes $\cdot$ Assimilation and fractional crystallization · Famatinian orogen

Manuel Demartis

mdemartis@exa.unrc.edu.ar

Stefan Jung

stefan.jung@uni-hamburg.de

1 Instituto de Ciencias de La Tierra, Biodiversidad y Ambiente (ICBIA) (UNRC-CONICET) - Departamento de Geología, FCEF-QyN, Universidad Nacional de Río Cuarto, Ruta Nacional 36 Km 601, X5804BYA Río Cuarto, Córdoba, Argentina

2 Fachbereich Geowissenschaften Mineralogisch-Petrographisches, Institut Universität Hamburg, 20146 Hamburg, Germany

3 GEOMAR Helmholtz Centre for Ocean Research Kiel, Wischhofstrasse 1-3, 24148 Kiel, Germany

4 Centro de Investigaciones Geológicas (CONICET, Universidad Nacional de La Plata), Diagonal 113 No. 275, B1904DPK La Plata, Argentina

\section{Introduction}

Granites are a major component of the Earth's continental crust and occur in a wide variety of tectonic settings. In most collisional belts, granites are either products of crustal anatexis or are derived by mantle-derived precursor magmas through differentiation. Partial melting of preexisting material may lead to the preservation of information about ancient crustal regions. Thus, an understanding of the composition of the sources is a major prerequisite for the reconstruction of the history of inaccessible portions of the deeper crust that were involved in tectonic and chemical processes occurred during an orogeny. Geochemical variations found within granitic plutons are either 
dominantly source-related or result from processes that occur during migration and crystallization of an original parent magma. Processes that may modify the composition of a magma body include mainly crystal fractionation processes with or without assimilation of pre-existing crustal rocks, magma mixing, restite unmixing or peritectic assemblage entrainment (see Clemens and Stevens 2012 for full discussion). These processes will ultimately result in chemical variation of the original magma and the occurrence of genetically related magma fractions. Usually, in mafic to intermediate rock series, well-defined chemical variation trends are observed, whereas in high- $\mathrm{SiO}_{2}$ magmas (such as pegmatite fields), extensive crystal fractionation processes can obscure fine-scale chemical differences between individual magma batches.

Particularly, the origin and evolution of highly evolved granitic magmas have been strongly debated through time (e.g., Chappell and White 1974, 1992, 2001; Barbarin 1996; Clemens et al. 2011; Castro 2014). One difficulty in evaluating models of granite petrogenesis is the lack of data that place limits on the ratio of components (lower crust, upper crust, mantle) involved in granite formation. $\mathrm{Nd}, \mathrm{Sr}$ and $\mathrm{Pb}$ isotopes are well suited for this purpose. As a general rule, mantle- or lower crustal-derived magmas with unradiogenic ${ }^{87} \mathrm{Sr} /{ }^{86} \mathrm{Sr}$ ratios and radiogenic $\mathrm{Nd}$ (positive $\varepsilon_{\mathrm{Nd}}$ ) contents may evolve through fractional crystallization, contamination and/or mixing with evolved crustal materials to give rise to granitic magmas with radiogenic ${ }^{87} \mathrm{Sr} /{ }^{86} \mathrm{Sr}$ ratios (usually $>0.715$ ) and unradiogenic $\varepsilon_{\mathrm{Nd}}$ values $(<-5)$ at their final stages (Carter et al. 1978; McCulloch and Chappell 1982; Hildreth et al. 1991; Davidson and de Silva 1992; Ort et al. 1996; Healy et al. 2004; Troll et al. 2005; Wang et al. 2016). However, the resultant negative correlations between $\mathrm{Sr}$ and $\mathrm{Nd}$ isotopes do not always take place in a balanced way. For example, hydrothermal alteration, contamination (Andrade et al. 1999; Kalsbeek and Frei 2006), retrograde metamorphism (Luais et al. 2001) or disequilibrium partial melting of a metasedimentary protolith involving certain minerals (Zeng et al. 2005a, b) could generate particular $\mathrm{Sr}$ and $\mathrm{Nd}$ isotope compositions that do not necessarily overlap with those of the surrounding rocks.

In this contribution, we present major and trace element data and $\mathrm{Nd}, \mathrm{Sr}$ and $\mathrm{Pb}$ isotopes of leucogranites and granitic pegmatites from the Comechingones pegmatitic field (CPF), Argentina (Fig. 1). Leucogranites and pegmatites from CPF crop out in a relatively narrow belt $(25 \mathrm{~km}$ long and $10 \mathrm{~km}$ wide) within the crustal-scale Guacha Corral shear zone, a first-order structure that juxtaposes terrains with different age domains (Pampean vs Famatinian). Particularly, some leucogranites show isotopic compositions that overlap with almost no other rock type from the geological framework in which they occur. The results presented here allowed us to discuss: (1) the water-fluxed partial melting of amphibolitic rocks to endow a primitive isotopic character to the highly evolved leucogranites, (2) the contribution of crustal materials (metasedimentary rocks) for the origin and evolution of the pegmatites and leucogranites, and (3) the combined effects of assimilation (contamination) and fractional crystallization to reach the particular isotope compositions of some leucogranite samples. Combining these results with previous geological and structural information, we finally discuss the role that the deformation of a crustal-scale shear zone, such as the Guacha Corral shear zone, have exerted on the fluid migration, partial melting and magma transport to higher structural levels. Our results reinforce the idea that anatectic processes and mass transport through the crust can efficiently take place in such a deformational setting, even hundreds of kilometers far from the arc in a foreland position.

\section{Geological setting and petrographic descriptions}

The CPF is located in the Sierras de Córdoba, central Argentina (Fig. 1a, b). These mountain ranges belong to the Sierras Pampeanas geological province, which consists of metamorphic rocks intruded mostly by Paleozoic igneous rocks (Jordan and Allmendiger 1986; Pankhurst and Rapela 1998). The metamorphic and igneous rocks of the Sierras Pampeanas were generated during three main orogenic events, namely the Pampean (late Neoproterozoic to Mid-Cambrian), Famatinian (Early to Mid-Ordovician), and Achalian (Late Devonian to Early Carboniferous) orogenies (Rapela et al. 1998a, b, 2018; Pankhurst et al. 1998; Sims et al. 1998; Stuart-Smith et al. 1999; Otamendi et al. 2004; Casquet et al. 2018; Weinberg et al. 2018).

Most of the Sierras de Córdoba are predominantly composed of metasedimentary (mostly siliciclastic sedimentary protoliths) and igneous rocks of Precambrian to Devonian age. During the Pampean orogeny, magmatic and mediumto high-grade (up to $7.5 \mathrm{~kb}$ and $850^{\circ} \mathrm{C}$; Rapela et al. 1998a; Otamendi et al. 2004) metamorphic events occurred in the Sierras de Córdoba producing gneisses, schists, migmatites (metatexites and diatexites), S- and I-type granitoid rocks and subordinate amphibolites, marbles, calc-silicate, mafic and ultramafic rocks (Rapela et al. 1998a; Otamendi et al. 2004; Iannizzotto et al. 2013; Murra et al. 2016; Casquet et al. 2018, among others). Afterwards, the Famatinian magmatic arc formed at the central and western portions of the Sierras Pampeanas, whereas in the Sierras de Córdoba, only a few igneous rocks of this age (Rapela et al. 1998a; D'Eramo et al. 2006, 2013, 2014 and references therein), some of them studied here, and shear zones are found. The latter accommodated significant exhumation of 


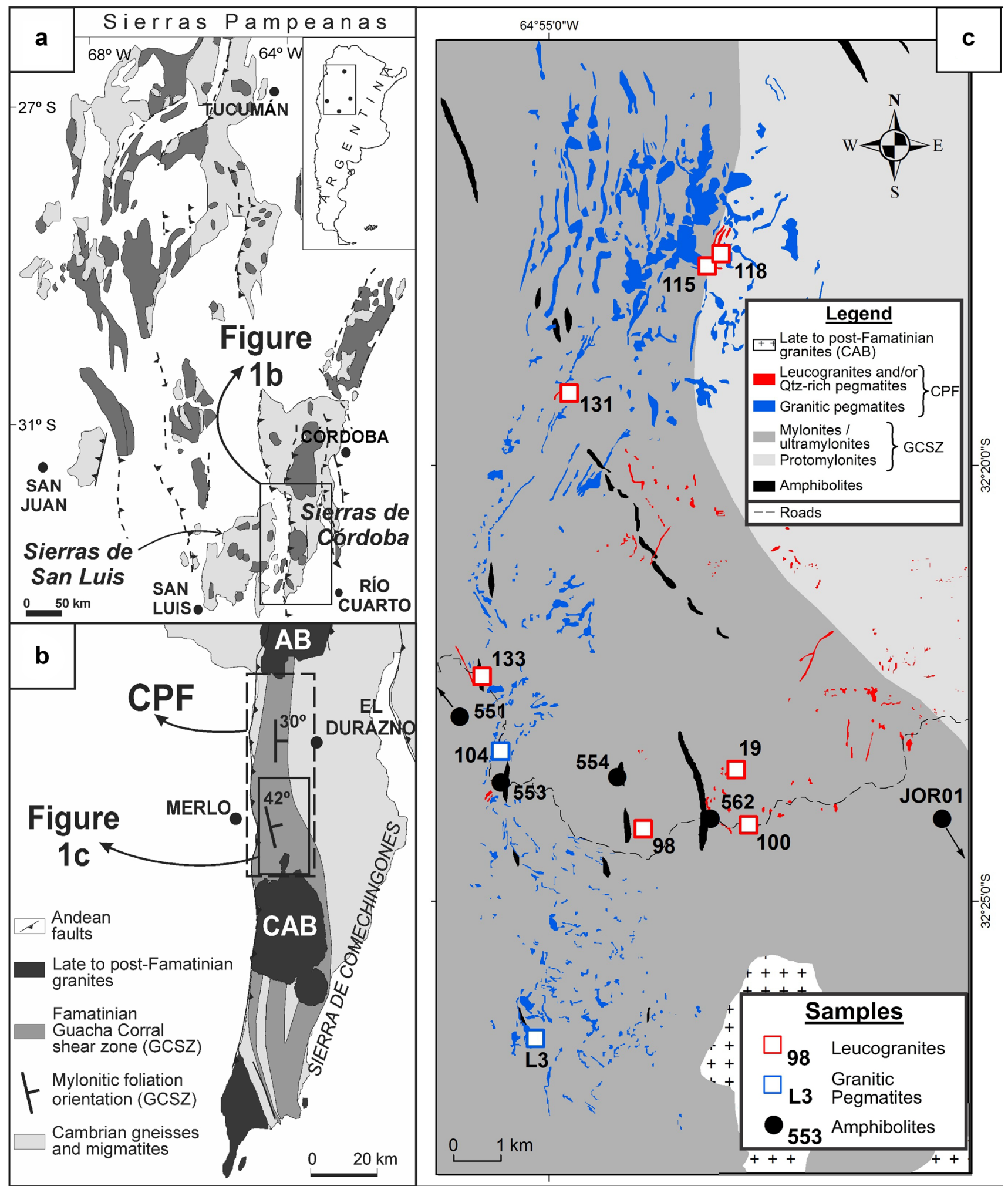

Fig. 1 a Geological sketch of the Sierras Pampeanas, Argentina, distinguishing the main metamorphic (light grey) and igneous (dark grey) rocks. b Simplified geological map of the Sierra de Comechingones, Córdoba. Insets: extension of Fig. 1c (continuous-line rectangle) and the Comechingones pegmatitic field (CPF; dashed-line rectangle). GCSZ: Guacha Corral Shear Zone; CAB: Cerro Áspero Batholith; AB: Achala Batholith. c Simplified geologic map of the study area, southern Comechingones pegmatitic field. Location of leucogranite, granitic pegmatite and amphibolite samples are shown along with their labels 
the metamorphic Pampean sequences (Rapela et al. 2018; Weinberg et al. 2018; Semenov et al. 2019). Finally, the Achalian orogeny was defined by Sims et al. (1998) and Stuart-Smith et al. (1999) to include tectonic and magmatic events that took place during predominantly Devonian times. The most representative Achalian igneous bodies in the Sierras de Córdoba are the Achala and Cerro Áspero batholiths (Lira and Sfragulla 2014 and references therein; Pinotti et al. 2002, 2006, 2014, 2016).

\section{Metamorphic country rocks}

In the study area, the country rocks of the leucogranites and pegmatites are dominated by aluminous metagreywacke sequences now represented by gneisses and migmatites (Otamendi et al. 1999, 2004; Demartis et al. 2011, 2017), and amphibolites. The Pampean gneisses and migmatites commonly have compositional banding, and stromatic and nebulitic structures, most of them completely reworked by the Guacha Corral shear zone deformation.

The Guacha Corral shear zone (Fig. 1b) is the largest and most complex ductile structure in the Sierras de Córdoba (Martino 2003; Whitmeyer and Simpson 2003; Otamendi et al. 2004; Fagiano 2007; Radice et al. 2015, 2020; Semenov and Weinberg 2017; Semenov et al. 2019). It is a $120 \mathrm{~km}$ long by $10 \mathrm{~km}$ wide shear belt that crops out in the central part of the Sierras de Córdoba, with a North-South trend, eastward dip and moderate dipping angle. The deformational history of the Guacha Corral shear zone points to protracted movements from Cambrian to Devonian times (Semenov et al. 2019), with deformational events that reworked the previous gneissic and migmatitic structures. The result of this reworking is the generation of $\mathrm{Bt}+\mathrm{Sil}$ (fibrolite) mylonites and $\mathrm{Chl}+$ Ser phyllonites (mineral abbreviations after Whitney and Evans 2010), formed during two main deformational events that took place at ductile, amphibolitefacies and ductile-brittle, greenschist-facies metamorphic conditions, with an almost reverse motion in a context of a compressive stress field for the ductile event (Martino et al. 1995; Martino 2003; Whitmeyer and Simpson 2003; Fagiano and Martino 2004; Fagiano et al. 2004; Otamendi et al. 2004; Fagiano 2007; Cristofolini et al. 2008; Steenken et al. 2010; Demartis et al. 2011; Radice et al. 2015; Semenov and Weinberg 2017; Semenov et al. 2019). According to its dimensions $(\sim 10 \mathrm{~km}$ width in its widest part and more than $100 \mathrm{~km}$ long) and the fact that it juxtaposes terranes with different tectono-metamorphic histories, the Guacha Corral shear zone is considered to be a crustal-scale structure, and was also proposed to be part of a larger thrust zone which would extend for at least $250 \mathrm{~km}$ (Whitmeyer and Simpson 2003; Weinberg et al. 2018; Semenov et al. 2019).

Amphibolites (Fig. 1c) are subordinate in area with respect to the gneisses and migmatites of the Sierras de
Córdoba. They crop out as tabular bodies that reach up to several kilometers in length and hundreds of meters in width. Banded structures defined by alternating bright and dark colored bands composed of plagioclase + diopside \pm quartz and hornblende + plagioclase + titanite, respectively, are common. The alternating bands and oriented hornblende crystals define a strong foliation that is partially overprinted by ductile deformation (Martino et al. 1995; Otamendi et al. 2004; Fagiano 2007; Cristofolini et al. 2008; Radice et al. 2015). Amphibolite bodies within the Guacha Corral shear zone were folded, boudinaged and strechted at the mega- and macro-scale forming individual bodies of smaller dimensions. Re-oriented, fractured and stretched amphibole crystals, as well as mechanical twins in plagioclase can be observed in deformed amphibolites.

\section{Leucogranites and granitic pegmatites}

The leucogranites and granitic pegmatites studied here (Demartis et al. 2011, 2014, 2017) yield LA-ICPMS U-Pb zircon ages of $474.8 \pm 12.2$ and $473.8 \pm 3.9 \mathrm{Ma}$, respectively, typical of the Famatinian orogeny (Demartis et al. 2017). They were grouped into the CPF, Sierras de Córdoba (Fig. 1b), which includes variably fractionated pegmatites, quartz-rich pegmatites and aplitic leucogranites.

The leucogranites occurs in a 12-km-long region located to the east of the Merlo village. They are relatively uncommon, and are distributed preferentially in the eastern side of the study area (Fig. 1c), spatially associated with quartzrich pegmatites. The leucogranites crop out as small tabular- to irregular-shaped bodies generally less than $5 \mathrm{~m}$ wide and between 10 and $200 \mathrm{~m}$ long (Fig. 2a), with mostly N-S strikes concordant to subconcordant with the mylonitic foliation of the host rocks.

Leucogranites are equigranular to weakly inequigranular, medium- to fine-grained rocks (Fig. 2b-d). Most samples were classified as monzogranites in the QAP diagram, although a few of them plotted in the granodiorite field. They consist of quartz, Ab-rich plagioclase, K-feldspar, muscovite and minor biotite with rare garnet. Accessory minerals are zircon, apatite, monazite and minor oxides. A continuous deformation from submagmatic to subsolidus conditions has been previously proposed (Demartis et al. 2017) according to textural, structural and microstructural evidence, such as microfractures filled with residual melt in early crystallized plagioclase crystals (Fig. 2c), chessboard extinction patterns in quartz grains, and preferred orientation of muscovite, biotite and quartz ribbons defining conspicuous S/C structures (Fig. 2b, d). The orientations of the $\mathrm{C}$ planes and the boundaries of the leucogranite bodies are usually parallel to the host mylonitic foliation. All these structural and microstructural observations, along with kinematic analysis at the mesoscale and 
Fig. 2 a Tabular-shaped body of leucogranite concordant with respect to the mylonitic foliation of the host rocks. The dike is $6 \mathrm{~m}$ long and $0.6 \mathrm{~m}$ thick (Demartis et al. 2017); b Photography at the hand-specimen scale of the leucogranites showing their general appearance and S/C structures defined by the preferred orientation of quartz, feldspars and micas (Demartis et al. 2017); c Microfractures in early crystallized plagioclase crystals in leucogranite, filled with residual melt (Demartis et al. 2017); d S/C structure at the microscopic scale in leucogranite, with fish-shaped muscovite and quartz ribbons defining the main $\mathrm{S}$ and $\mathrm{C}$ planes (Demartis et al. 2017); e Typical internal zonation in granitic pegmatites, composed, from contact inwards, of border, wall, intermediate and core zones; dike width is approximately $25 \mathrm{~m}$; f Intermediate zone of a granitic pegmatite showing a well-developed internal foliation defined by flattened, stretched and reoriented coarse-grained microcline, quartz ribbons, and micas; pen length is $14 \mathrm{~cm}$ (Demartis et al. 2011); (g) Wedge-shaped intracrystalline fracture in feldspar crystals from the intermediate zone of a granitic pegmatitic, filled with residual melt (Demartis et al. 2011); (h) Albite perthites with flame shapes in large microcline grain from the intermediate zone of a granitic pegmatite (Demartis et al. 2011). All photomicrographs are under cross-polarized light

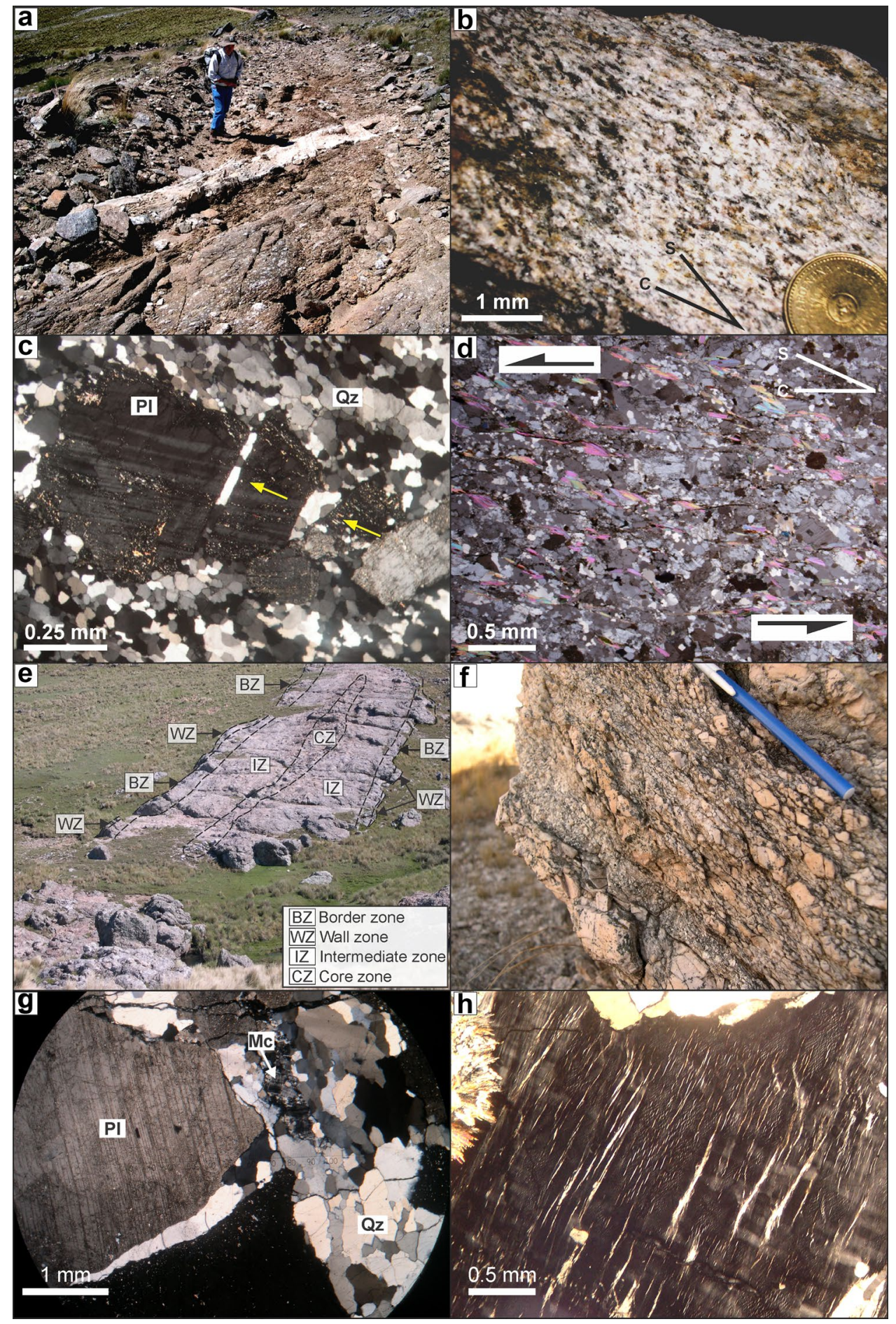

microscale yielding the same sense of shearing between leucogranites and the host mylonites, indicate a synkinematic emplacement of the former with respect to the hightemperature ductile event of the Guacha Corral shear zone (Demartis et al. 2017).

Granitic pegmatites crop out in the western part of the studied area (Fig. 1c), where the mylonitic country rocks show the most pervasive deformation. They consist of variable-sized, tabular- to lens-shaped composite bodies. They commonly show internal zonation comprised by border, wall, intermediate and core zones (Fig. 2e; Demartis et al. 2011). The majority of the pegmatites displays low to intermediate degrees of fractionation and are usually barren (no metalliferous mineralization) bodies. However, rare-element mineralizations have also been described in some pegmatites (Galliski 1994; Demartis et al. 2011, 2014), where 
accessory minerals (garnet, $\mathrm{Fe}-\mathrm{Mn}$ phosphates, uraninite, beryl, columbite-group, Li-rich micas and tourmaline, among others) indicative of typical LCT (Li-Cs-Ta; Černý and Ercit 2005) geochemical signatures are present. Highly evolved, late-stage replacement units of metasomatic origin have also been observed in a few pegmatites (Demartis et al. 2014). These units are the result of internal recirculation of late-pegmatitic fluids that affects the previously crystallized zones leading to extreme enrichment in some elements $(\mathrm{Li}$, Cs, F, Ta, Hf, etc.; Demartis et al. 2014).

An internal foliation defined by flattened, stretched and reoriented coarse-grained microcline (Fig. 2f), quartz ribbons and muscovite is commonly observed in the pegmatites at the outcrop scale. This foliation, as well as the mean planar orientation of most of the pegmatite bodies, is usually oriented parallel to the mylonitic foliation of the country rocks (Demartis et al. 2011, 2017). Structural and microstructural evidence, such as wedge-shaped intracrystalline fractures filled with residual melt in large feldspar crystals (Fig. 2g), mechanical twins in feldspars, chessboard extinction patterns in quartz, and albitic perthites with flame shapes in large microcline grains (Fig. 2h), among others, also point to a continuous deformation from the submagmatic to subsolidus conditions (Demartis et al. 2011, 2017). The above-mentioned textural, structural and microstructural evidence, along with detailed kinematic analysis, allowed some authors to suggest a synkinematic emplacement of the granitic pegmatites with the main deformational event of the Guacha Corral shear zone (Steenken et al. 2010; Demartis et al. 2011, 2017; Semenov et al. 2019). Space generation is difficult to explain in the contractional setting in which these rocks were emplaced, such as that occurred during the ductile deformational event of the Guacha Corral shear zone. Demartis et al. (2011) have proposed an emplacement mechanism in which local and temporal spaces were opened due to displacements along staggered shear zones with releasing bends, inducing the local development of domains with negative pressure gradients and "pumping" magmas towards these sites, thus allowing their transport upwards in the shear zone.

\section{Analytical techniques}

Major and trace elements, as well as $\mathrm{Sr}-\mathrm{Nd}$ isotope geochemistry, were performed on seven leucogranite and two pegmatite whole rock samples. Small pegmatite dikes were chosen for sampling. To assure representative sampling including textural and mineralogical inhomogeneities, each sample comprised several rock chips of hundreds of grams taken representatively from the different internal zones across the pegmatites. Pegmatite sampling was performed on relatively small dikes (less than $1 \mathrm{~m}$ thick) to collect the whole material across the internal zoning. Five samples of amphibolites were also sampled for major and trace element geochemistry (sample location in Fig. 1c). For the Pb isotopes analysis, inclusion- and alteration-free K-feldspar grains were selected under binocular microscope from previously crushed whole rock leucogranite and pegmatite samples.

Whole-rock major and trace element compositions of leucogranites and pegmatites were measured by ICP-MS at Activation Laboratories (Actlabs; Canada). Five amphibolite whole-rock samples were also measured for major and trace element concentrations on fused lithium-tetraborate glass beads using standard XRF techniques and a PanAnalytical MagixPro X-ray fluorescence spectrometer at the Universität Hamburg. Estimated uncertainties are 1-2\% relative.

Strontium, $\mathrm{Nd}$ and $\mathrm{Pb}$ isotope analyses were carried out at the GEOMAR Helmholtz-Zentrum für Ozeanforschung Kiel by thermal ionization mass spectrometry using a Finnigan MAT 262 multi sample, multi-collector mass spectrometer operating in static mode. Strontium and REE were separated using standard cation exchange columns with a DOWEX ${ }^{\circledR}$ AG 50W-X 12 resin using $2.5 \mathrm{~N} \mathrm{HCl}$ for $\mathrm{Sr}$ and $6 \mathrm{~N} \mathrm{HCl}$ for the REE. Neodymium was separated from the other REE using HDEHP-coated Teflon ${ }^{\circledR}$ columns and $0.12 \mathrm{~N} \mathrm{HCl}$. Neodymium isotopes were normalized to ${ }^{146} \mathrm{Nd} /{ }^{144} \mathrm{Nd}=0.7219$. Repeated measurements of the La Jolla Nd standard gave ${ }^{143} \mathrm{Nd} /{ }^{144} \mathrm{Nd}=0.511829 \pm 0.0$ 00003 ( 2 sigma; $n=4$ ). The reproducibility of the $\mathrm{Sr}$ standard (NBS 987) is ${ }^{87} \mathrm{Sr} /{ }^{86} \mathrm{Sr}=0.710271 \pm 0.000003$ ( 2 sigma; $\left.n=8\right)$ and the fractionation was corrected to ${ }^{86} \mathrm{Sr} /{ }^{88} \mathrm{Sr}=0.1194$. A detailed description of the $\mathrm{Pb}$ (Double Spike; DS) isotope analyses performed at IFM-GEOMAR (Kiel, Germany) is found in Hoernle et al. (2011). K-feldspar separates were washed overnight in aqua regia and subsequently triple rinsed with ultrapure water thereafter. The separates were leached three times in a mixture of concentrated $\mathrm{HF}$ and $\mathrm{HNO}_{3}$ which resulted in a weight loss of c. 50\%. After this treatment, the separates were dissolved in a 1:5 mixture of concentrated ultra-pure $\mathrm{HNO}_{3}$ and $\mathrm{HF}$ at $150{ }^{\circ} \mathrm{C}$, followed by standard chromatography procedures. Lead isotope ratios were determined on a Finnigan MAT262 TIMS using the silica gel technique. DS corrected NBS 981 values $(n=87 ; 2009-2011)$ with corresponding 2 sigma external uncertainties are ${ }^{206} \mathrm{~Pb} /{ }^{204} \mathrm{~Pb}=16.9418 \pm 0.0025$, ${ }^{207} \mathrm{~Pb} /{ }^{204} \mathrm{~Pb}=15.4998 \pm 0.0024,{ }^{208} \mathrm{~Pb} /{ }^{204} \mathrm{~Pb}=36.7252 \pm 0.0062$, ${ }^{207} \mathrm{~Pb} /{ }^{206} \mathrm{~Pb}=0.91488 \pm 0.00004$ and ${ }^{208} \mathrm{~Pb} /{ }^{206} \mathrm{~Pb}=2.16773 \pm 0$ .00009 . Typical total chemistry blanks range from 10 to $30 \mathrm{pg}$ $\mathrm{Pb}$.

\section{Results}

\section{Major and trace elements}

Leucogranites and pegmatites are geochemically evolved rocks, with high silica contents (75.08-77.72 wt \%). They 
have low concentrations of $\mathrm{Fe}_{2} \mathrm{O}_{3}, \mathrm{MgO}, \mathrm{TiO}_{2}$ and $\mathrm{CaO}$ and are enriched in alkalis $\left(\mathrm{Na}_{2} \mathrm{O}\right.$ and $\left.\mathrm{K}_{2} \mathrm{O}\right)$ and moderately enriched in $\mathrm{P}_{2} \mathrm{O}_{5}$ (Table 1). All samples are peraluminous, with ASI values [Aluminium Saturation Index: molecular $\left.\mathrm{Al}_{2} \mathrm{O}_{3} /\left(\mathrm{CaO}+\mathrm{Na}_{2} \mathrm{O}+\mathrm{K}_{2} \mathrm{O}\right)\right]$ between 1.37 and 1.66 for leucogranites, and as high as 1.76 for pegmatites. Due to their high $\mathrm{SiO}_{2}$ contents, inter-element variations with respect to $\mathrm{SiO}_{2}$ are obscured. However, some rough covariations can be observed, in which some major oxides show a decrease $\left(\mathrm{MgO}, \mathrm{Fe}_{2} \mathrm{O}_{3}\right.$ and $\left.\mathrm{Al}_{2} \mathrm{O}_{3}\right)$ or increase $\left(\mathrm{K}_{2} \mathrm{O}\right.$ and $\left.\mathrm{Na}_{2} \mathrm{O}\right)$ with increasing $\mathrm{SiO}_{2}$ contents.

Trace element abundances are also variable and clear covariations are difficult to identify. Abundances of Eu, Ba and $\mathrm{Sr}$ are roughly positively correlated, as well as $\mathrm{Y}$, Th and the REE (Fig. 3). Pegmatites almost invariably show the lowest contents of these trace elements when compared to leucogranites (Fig. 3). Among the leucogranite samples, positive trends can be observed in the bivariate diagrams (Fig. 3). A group of three samples (samples 19, 100 and 118) have the highest $\mathrm{Eu}, \mathrm{Ba}$ and $\mathrm{Sr}$ contents (Fig. $3 \mathrm{a}$ and $3 \mathrm{~b}$ ). Positive covariations can also be observed in the $(\mathrm{La} / \mathrm{Yb})_{\mathrm{N}}$ vs total REE (Fig. 3c), (La/Yb) $)_{\mathrm{N}}$ vs Y (Fig. 3d), total REE vs Y (Fig. 3e) and total REE vs Th (Fig. 3f) diagrams. Two samples (samples 19 and 100) have the highest total REE and Th abundances, and yield relatively high $\mathrm{Y}$ contents. Two trends with distinctive slopes can be observed in the $(\mathrm{La} / \mathrm{Yb})_{N}$ vs Y (Fig. 3d) and total REE vs Y (Fig. 3e) diagrams: strong vs slight increase in $(\mathrm{La} / \mathrm{Yb})_{\mathrm{N}}$ ratios and total REE contents with increasing $\mathrm{Y}$, being the steeper slopes in both diagrams defined by samples 19 and 100. Finally, two samples (98 and 118) display the highest HREE and Y contents (Table 1).

Rare-earth element abundances are variable, and different patterns are observed (Fig. 4). Leucogranites show total REE contents ranging from 15.3 to $129 \mathrm{ppm}$, whereas pegmatites have less than $11 \mathrm{ppm}$ (Table 1). Fractionation of LREE relative to HREE is also variable with La/ $\mathrm{Yb}_{(\mathrm{N})}$ ratios ranging from 1.55 to 16.3 in leucogranites and around 1 in pegmatites. As was previously reported, the highest $\mathrm{La} / \mathrm{Yb}_{(\mathrm{N})}$ ratios are confined to the samples with the highest total REE contents (Fig. 3c). Europium anomalies are moderately negative or non-existent in leucogranites, with $\mathrm{Eu} / \mathrm{Eu}$ * ranging between 0.5 and 1.0. Pegmatites show positive Eu anomalies, with $\mathrm{Eu} / \mathrm{Eu}^{*}$ between 2.60 and 1.98 (Fig. 4; Table 1).

\section{$\mathrm{Nd}, \mathrm{Sr}$ and $\mathrm{Pb}$ isotopes}

The results of the $\mathrm{Sr}, \mathrm{Nd}$ and $\mathrm{Pb}$ isotope analyses are reported in Table 2. Initial ${ }^{87} \mathrm{Sr} /{ }^{86} \mathrm{Sr}$ ratios and $\varepsilon_{\mathrm{Nd}}$ values were recalculated according to an age of $475 \mathrm{Ma}$ (Demartis et al. 2017). Leucogranites have remarkable variations in the $\mathrm{Nd}$ and $\mathrm{Sr}$ isotope compositions. Initial $\varepsilon_{\mathrm{Nd}}$ values vary in a relatively narrow range from +2.0 to -3.1 , whereas initial ${ }^{87} \mathrm{Sr} /{ }^{86} \mathrm{Sr}$ ratios range from 0.7048 to 0.7170 (Fig. 5). These variations define a linear trend with two end members: samples with relatively primitive isotopic characters (unradiogenic initial ${ }^{87} \mathrm{Sr} /{ }^{86} \mathrm{Sr}$ ratios and radiogenic $\varepsilon_{\mathrm{Nd}}$ values) and samples with a radiogenic initial ${ }^{87} \mathrm{Sr} /{ }^{86} \mathrm{Sr}$ ratios and relatively unradiogenic $\varepsilon_{\mathrm{Nd}}$ values. Compared to leucogranites, pegmatites show more unradiogenic initial $\varepsilon_{\mathrm{Nd}}$ values $(-7.5$ and -8.4$)$. They show radiogenic initial ${ }^{87} \mathrm{Sr} /{ }^{86} \mathrm{Sr}$ ratios $(0.7149$ and 0.7167$)$, quite similar to the most evolved leucogranite samples. When plotted against the available $\mathrm{Sr}$ and $\mathrm{Nd}$ isotopic compositions of the main igneous and metamorphic rocks with pre-Famatinian ages, pegmatite samples overlap the available compositions of the metasedimentary rocks (schists, phyllites, paragneisses and migmatites) from the Sierras de Córdoba (Table 3). The most primitive samples of leucogranites plot within the compositions of only minor rock types (amphibolites); the rest of the samples defining the linear trend plot above the pre-Famatinian crustal rocks from the Sierras de Córdoba and Famatinian igneous rocks (Fig. 5a, b).

The results of $\mathrm{Pb}$ isotope analyses on acid-leached feldspars are reported in Table 2 and shown in Fig. 6a, b. The ${ }^{206} \mathrm{~Pb} /{ }^{204} \mathrm{~Pb}$ and ${ }^{207} \mathrm{~Pb} /{ }^{204} \mathrm{~Pb}$ ratios obtained from both rock types partially overlap and range from 18.23 to 18.43 and from 15.64 to 15.68 , respectively. The ${ }^{208} \mathrm{~Pb} /{ }^{204} \mathrm{~Pb}$ ratios range from 37.99 to 38.26 . When plotted together with the growth curves for various reservoirs of the plumbotectonic model proposed by Zartman and Doe (1981), data for both rock types plot close to, or above, the upper continental crust growth curve. Leucogranite samples also show some scatter towards the 'orogene' curve of Zartman and Doe (1981) (Fig. 6a, b).

\section{Discussion}

\section{Primitive isotopic signatures: partial melting of amphibolites?}

The unradiogenic initial ${ }^{87} \mathrm{Sr} /{ }^{86} \mathrm{Sr}$ ratios and radiogenic $\varepsilon_{\mathrm{Nd}}$ values of the most primitive samples of the leucogranites (e.g. samples 98 and 19) indicate that part of their sources are isotopically unevolved rocks. Such primitive characters of the leucogranites are difficult to explain since the majority of the pre-Famatinian igneous and metamorphic rocks that comprise the Sierras de Córdoba have isotopic signatures similar to typical crustal rocks with negative initial $\varepsilon_{\mathrm{Nd}}$ values and radiogenic initial ${ }^{87} \mathrm{Sr} /{ }^{86} \mathrm{Sr}$ ratios (Fig. 5; Table 3). Rocks displaying rather unradiogenic initial ${ }^{87} \mathrm{Sr} /{ }^{86} \mathrm{Sr}$ ratios and positive $\varepsilon_{\mathrm{Nd}}$ values in the Sierras de Córdoba (Table 3) are mostly Pampean-aged amphibolites 
Table 1 Whole rock major and trace element compositions of leucogranites and pegmatites from Comechingones field, Sierras de Córdoba

\begin{tabular}{|c|c|c|c|c|c|c|c|c|c|}
\hline & \multicolumn{7}{|c|}{ Leucogranite } & \multicolumn{2}{|c|}{ Pegmatite } \\
\hline & 19 & 115 & 133 & 98 & 100 & 118 & 131 & L3 & $104-1$ \\
\hline \multicolumn{10}{|c|}{ Major elements (wt\%) } \\
\hline $\mathrm{SiO}_{2}$ & 77.72 & 76.39 & 76.27 & 75.67 & 75.08 & 75.56 & 75.56 & 76.46 & 77.28 \\
\hline $\mathrm{TiO}_{2}$ & 0.08 & 0.02 & 0.02 & 0.04 & 0.11 & 0.02 & 0.06 & 0.01 & 0.01 \\
\hline $\mathrm{Al}_{2} \mathrm{O}_{3}$ & 13.75 & 14.53 & 14.64 & 15.46 & 14.46 & 14.56 & 15.29 & 14.69 & 14.11 \\
\hline $\mathrm{Fe}_{2} \mathrm{O}_{3(\mathrm{~T})}$ & 0.88 & 0.74 & 0.58 & 0.82 & 1.00 & 0.74 & 0.82 & 0.50 & 0.21 \\
\hline $\mathrm{MnO}$ & 0.01 & 0.07 & 0.03 & 0.05 & 0.02 & 0.05 & 0.02 & 0.01 & 0.01 \\
\hline $\mathrm{MgO}$ & 0.17 & 0.06 & 0.12 & 0.15 & 0.25 & 0.05 & 0.20 & 0.11 & 0.05 \\
\hline $\mathrm{CaO}$ & 0.98 & 0.77 & 0.65 & 0.80 & 0.49 & 0.92 & 0.53 & 0.27 & 0.85 \\
\hline $\mathrm{Na}_{2} \mathrm{O}$ & 2.60 & 2.97 & 2.92 & 3.16 & 3.22 & 2.95 & 3.59 & 2.06 & 4.45 \\
\hline $\mathrm{K}_{2} \mathrm{O}$ & 2.47 & 2.67 & 2.61 & 3.43 & 3.56 & 3.80 & 2.81 & 4.11 & 2.61 \\
\hline $\mathrm{P}_{2} \mathrm{O}_{5}$ & 0.04 & 0.05 & 0.15 & 0.19 & 0.05 & 0.06 & 0.11 & 0.12 & 0.15 \\
\hline LOI & 1.48 & 1.43 & 1.45 & 1.22 & 1.44 & 1.09 & 1.40 & 1.47 & 0.73 \\
\hline Total & 100.20 & 99.71 & 99.44 & 101.00 & 99.69 & 99.81 & 100.40 & 99.79 & 100.50 \\
\hline $\mathrm{ASI}^{\mathrm{a}}$ & 1.57 & 1.58 & 1.66 & 1.49 & 1.44 & 1.37 & 1.54 & 1.76 & 1.21 \\
\hline \multicolumn{10}{|c|}{ Trace elements (ppm) } \\
\hline $\mathrm{Li}$ & 15 & 3 & 6 & 8 & 26 & 3 & 7 & 6 & 6 \\
\hline $\mathrm{Ga}$ & 20 & 20 & 13 & 16 & 19 & 18 & 15 & 9 & 9 \\
\hline $\mathrm{Rb}$ & 70 & 105 & 83 & 127 & 110 & 96 & 84 & 105 & 64 \\
\hline $\mathrm{Sr}$ & 82 & 35 & 41 & 38 & 103 & 70 & 38 & 37 & 60 \\
\hline $\mathrm{Y}$ & 15.2 & 12.7 & 7.0 & 18.0 & 12.0 & 14.0 & 9.0 & 3.0 & 5.0 \\
\hline $\mathrm{Zr}$ & 73 & 30 & 20 & 38 & 80 & 29 & 31 & 4 & 45 \\
\hline $\mathrm{Nb}$ & 8.4 & 11.5 & 6.5 & 11.0 & 10.0 & 8.0 & 8.0 & 3.0 & 2.0 \\
\hline Cs & 1.8 & 1.0 & 2.0 & 2.6 & 4.4 & 0.6 & 1.8 & 2.9 & 1.3 \\
\hline $\mathrm{Ba}$ & 387 & 193 & 62 & 137 & 413 & 393 & 141 & 144 & 56 \\
\hline $\mathrm{La}$ & 27.6 & 6.5 & 2.7 & 6.5 & 17.4 & 7.1 & 4.5 & 0.8 & 1.9 \\
\hline $\mathrm{Ce}$ & 58.1 & 14.0 & 5.2 & 15.6 & 36.6 & 15.2 & 8.8 & 1.2 & 3.4 \\
\hline $\operatorname{Pr}$ & 6.37 & 1.60 & 0.55 & 1.95 & 4.38 & 1.87 & 1.09 & 0.17 & 0.42 \\
\hline $\mathrm{Nd}$ & 22.1 & 6.74 & 2.11 & 8.10 & 14.4 & 7.50 & 4.10 & 0.60 & 1.70 \\
\hline $\mathrm{Sm}$ & 4.25 & 1.62 & 0.56 & 2.00 & 3.00 & 1.90 & 1.00 & 0.20 & 0.50 \\
\hline $\mathrm{Eu}$ & 0.90 & 0.27 & 0.18 & 0.37 & 0.71 & 0.50 & 0.31 & 0.17 & 0.29 \\
\hline $\mathrm{Gd}$ & 3.64 & 1.73 & 0.54 & 2.40 & 2.20 & 2.00 & 1.00 & 0.20 & 0.40 \\
\hline $\mathrm{Tb}$ & 0.56 & 0.37 & 0.14 & 0.50 & 0.40 & 0.40 & 0.20 & 0.05 & 0.10 \\
\hline Dy & 2.69 & 2.22 & 1.00 & 3.10 & 2.30 & 2.70 & 1.60 & 0.40 & 0.70 \\
\hline Ho & 0.46 & 0.37 & 0.21 & 0.60 & 0.40 & 0.50 & 0.30 & 0.10 & 0.15 \\
\hline $\mathrm{Er}$ & 1.29 & 1.07 & 0.68 & 1.90 & 1.10 & 1.40 & 1.00 & 0.40 & 0.50 \\
\hline $\mathrm{Tm}$ & 0.18 & 0.16 & 0.15 & 0.32 & 0.16 & 0.21 & 0.20 & 0.09 & 0.10 \\
\hline $\mathrm{Yb}$ & 1.14 & 0.99 & 1.16 & 2.10 & 0.90 & 1.30 & 1.40 & 0.70 & 0.70 \\
\hline $\mathrm{Lu}$ & 0.16 & 0.13 & 0.18 & 0.31 & 0.13 & 0.17 & 0.19 & 0.11 & 0.10 \\
\hline Hf & 3.00 & 1.90 & 1.00 & 1.60 & 2.40 & 1.70 & 1.20 & 0.30 & 1.10 \\
\hline $\mathrm{Ta}$ & 2.58 & 4.25 & 3.96 & 3.60 & 2.10 & 2.60 & 2.70 & 2.20 & 1.80 \\
\hline W & 676 & 770 & 540 & 469 & 478 & 540 & 457 & 447 & 520 \\
\hline $\mathrm{Pb}$ & 12 & 20 & 28 & 29 & 19 & 25 & 53 & 39 & 37 \\
\hline Th & 11.1 & 3.15 & 0.97 & 3.70 & 8.00 & 4.20 & 1.90 & 0.20 & 0.30 \\
\hline $\mathrm{U}$ & 1.02 & 1.24 & 1.16 & 2.20 & 0.80 & 1.70 & 1.50 & 0.40 & 0.50 \\
\hline$\sum \mathrm{REE}$ & 129.4 & 37.8 & 15.3 & 45.8 & 84.1 & 42.8 & 25.7 & 5.2 & 11.0 \\
\hline
\end{tabular}

LOI loss of ignition

${ }^{\mathrm{a}} \mathrm{ASI}$ (Aluminum saturation index $)=[\mathrm{Al} /(\mathrm{Na}+\mathrm{K}+\mathrm{Ca})]_{\text {molar }}$ 

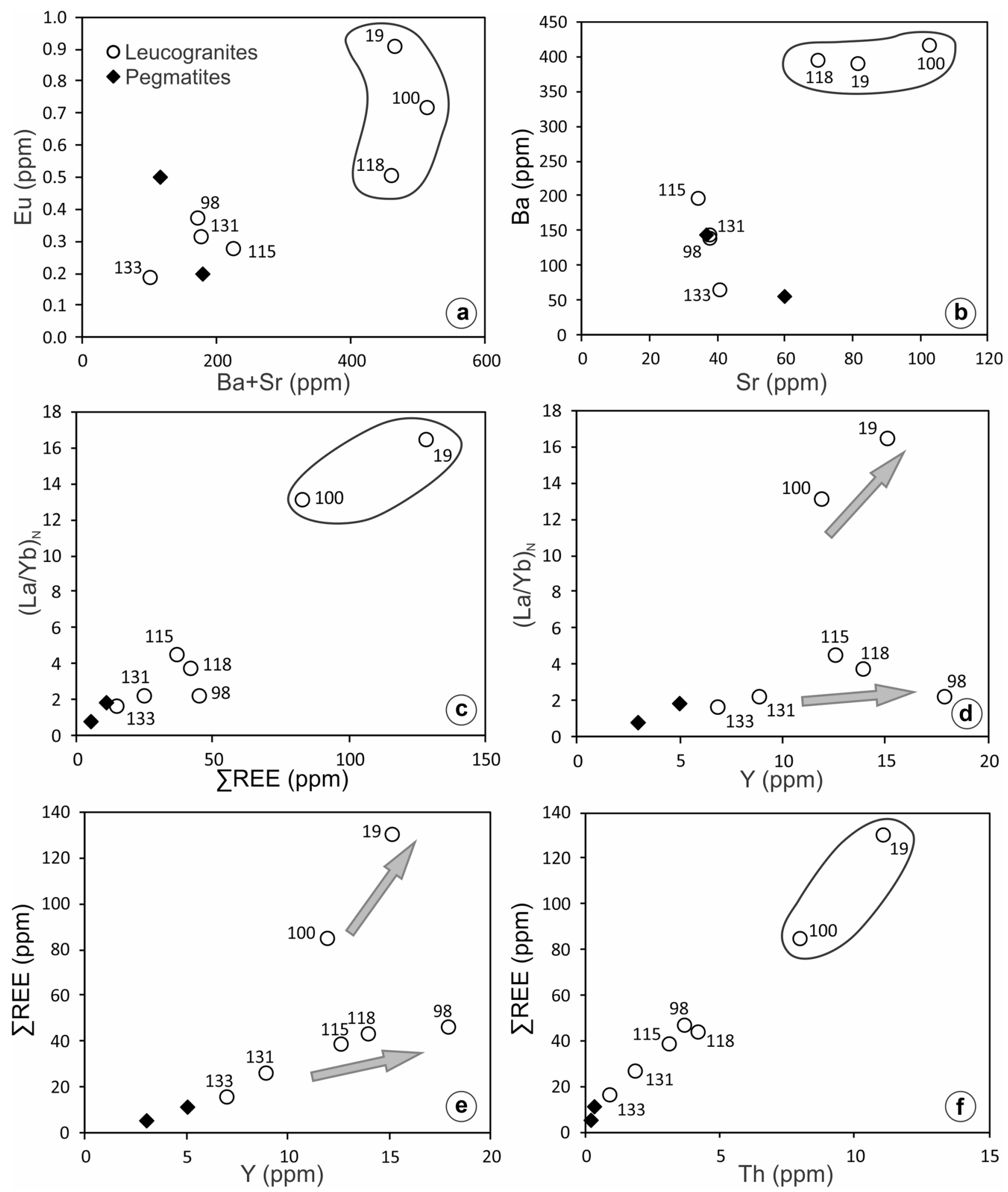

Fig. 3 Bivariate diagrams for leucogranites and granitic pegmatites from the CPF. a $\mathrm{Ba}+\mathrm{Sr}$ vs $\mathrm{Eu}$; b $\mathrm{Sr}$ vs $\mathrm{Ba} ; \mathbf{c} \Sigma \mathrm{REE}$ vs $(\mathrm{La} / \mathrm{Y})_{\mathrm{N}}$; d Y vs $(\mathrm{La} / \mathrm{Y})_{\mathrm{N}} ; \mathbf{e} \mathrm{Y}$ vs $\Sigma \mathrm{REE} ; \mathbf{f}$ Th vs $\Sigma \mathrm{REE}$. La/Y ratios normalized to chondrite values from Boynton (1984) 

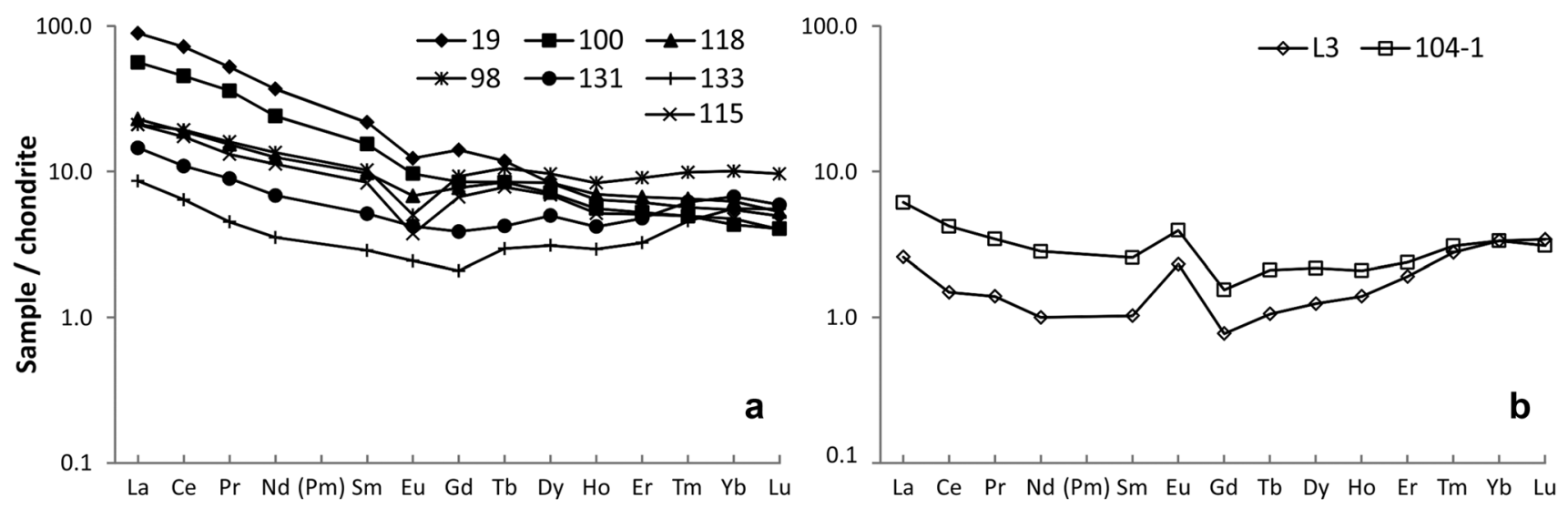

Fig. 4 Chondrite-normalized REE diagrams for: a leucogranites, and b granitic pegmatites from the CPF. Chondrite values from Boynton (1984)

and mafic-ultramafic rocks (Rapela et al. 1998a; Escayola et al. 2007).

The initial ${ }^{87} \mathrm{Sr} /{ }^{86} \mathrm{Sr}$ ratios and initial $\varepsilon_{\mathrm{Nd}}$ values reported by Rapela et al. (1998a) and Steenken et al. (2011) for amphibolites in the Sierras de Córdoba were recalculated here to the age of the leucogranites (475 Ma; Demartis et al. 2017), yielding ${ }^{87} \mathrm{Sr} /{ }^{86} \mathrm{Sr}_{(475)}$ ratios and $\varepsilon_{\mathrm{Nd}(475)}$ values between 0.7042 and 0.7066 and between -4.3 and +9.6 , respectively. Although much less abundant compared to the metasedimentary rocks, amphibolites are common in the study area (Fig. 1c) and in several parts of the Sierras de Córdoba. Therefore, the leucogranites can be regarded a priori as amphibolite-derived melts that then evolved by other processes.

To go further on this idea, five amphibolite samples from Sierra de Comechingones (Fig. 1c) were analyzed. Major element geochemistry of the amphibolites (Table 4) indicate that these rocks have low $\mathrm{SiO}_{2}(46.39-48.06 \%)$ and alkali element abundances $\left(\mathrm{Na}_{2} \mathrm{O}: 1.84-3.37 \mathrm{wt} \%\right.$; $\left.\mathrm{K}_{2} \mathrm{O}: 0.42-0.68 \mathrm{wt} \%\right)$ and high $\mathrm{CaO}(9.92-13.73 \mathrm{wt} \%)$, $\mathrm{Al}_{2} \mathrm{O}_{3}(14.00-16.36 \mathrm{wt} \%), \mathrm{Fe}_{2} \mathrm{O}_{3(\mathrm{~T})}(9.70-14.29 \mathrm{wt} \%)$, and $\mathrm{MgO}$ (5.07-9.19 wt\%) contents.

Dehydration melting of amphibolitic rocks with rather similar compositions (Beard and Lofgren 1991; Rapp et al. 1991; Rushmer 1991; Wolf and Wyllie 1991, 1994; Sen and Dunn 1994; Rapp and Watson 1995; Winther 1996; López and Castro 2001; Zhang et al. 2013) gives rise to melts with generally tonalitic-trondhjemitic (or less commonly granodioritic) compositions at high $\mathrm{P}-\mathrm{T}$ conditions (generally $>850-900{ }^{\circ} \mathrm{C}$ and $0.8 \mathrm{GPa}$ ), and usually consumes hornblende at higher temperatures. By contrast, water-fluxed melting of the same amphibolitic rocks (Beard and Lofgren 1991; Rapp et al. 1991; Tepper et al. 1993; Lee and Cho 2013; Palin et al. 2016; Yakymchuk et al. 2019) usually yields tonalitic to granodioritic melts, although granitic melt compositions (i.e., high $\mathrm{SiO}_{2}$, $\mathrm{K}_{2} \mathrm{O}$ and $\mathrm{Na}_{2} \mathrm{O}$, and low $\mathrm{CaO}, \mathrm{FeO}$ and $\mathrm{MgO}$ ) generated directly from mafic sources by water-fluxed melting at lower $\mathrm{P}$ and $\mathrm{T}$ conditions have also been reported by some authors (Tepper et al. 1993; Palin et al. 2016). Tepper et al. (1993) proposed a model in which water fugacity played a crucial role in the melt compositions during melting processes. They state that hydrous (water-fluxed) vs dehydration melting of an amphibole-bearing mafic lower crust would have produced granodioritic-granitic vs tonalitic melts, respectively, with heat and fluids provided by mantle-derived (anhydrous vs hydrated) basalts that were emplaced into this lower crust. Since isotopic compositions do not show significant changes among rock types, Tepper et al. (1993) considered all granitoids (tonalitic to granitic rocks) as melts generated from a single source, but due to different melting conditions (dehydration vs water-fluxed). In addition, Palin et al. (2016) calculated the compositions of MORB- and diorite-derived melts, showing that melting reactions that take place at relatively low $\mathrm{T}$ reach major oxide compositions that plot in the granite field with $\mathrm{K}_{2} \mathrm{O}$ contents $>3$ wt $\%$.

Considering the geochemical and isotopic compositions of the most primitive leucogranite samples, along with the major, trace and isotope compositions of the amphibolites that crop out in the Sierra de Comechingones and the geodynamic framework of the study area during the Famatinian orogen (see "Discussion" below), we here propose that water-fluxed melting of the amphibolites could have yielded now unexposed granodioritic or granitic melts with unradiogenic initial ${ }^{87} \mathrm{Sr} /{ }^{86} \mathrm{Sr}$ ratios and radiogenic $\varepsilon_{\mathrm{Nd}}$ values. Water-assisted melting, as proposed by some authors (Tepper et al. 1993; Lee and Cho 2013; Yakymchuk et al. 2019), would stabilize peritectic hornblende, thus reducing the $\mathrm{FeO}_{\mathrm{T}}$ and $\mathrm{MgO}$ contents in the resultant melt. 


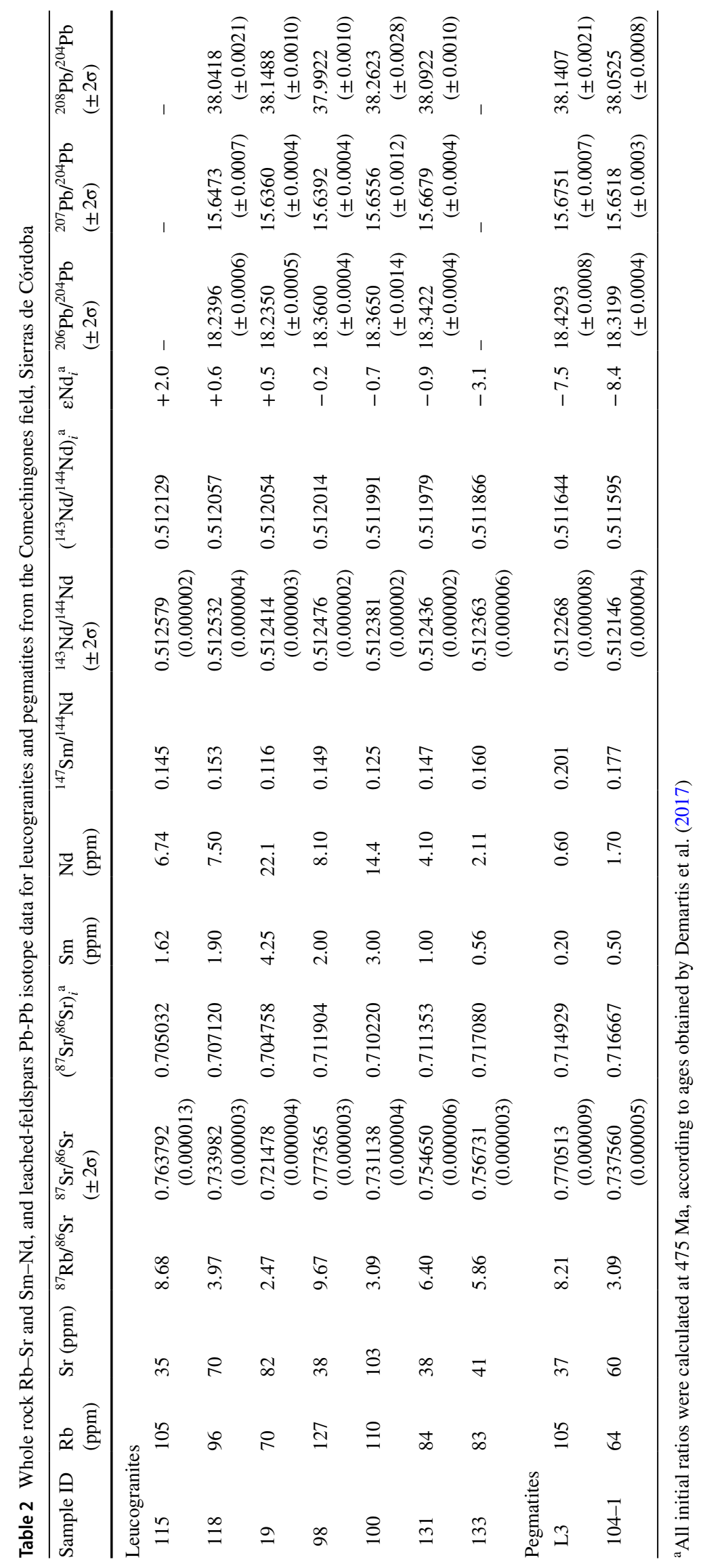



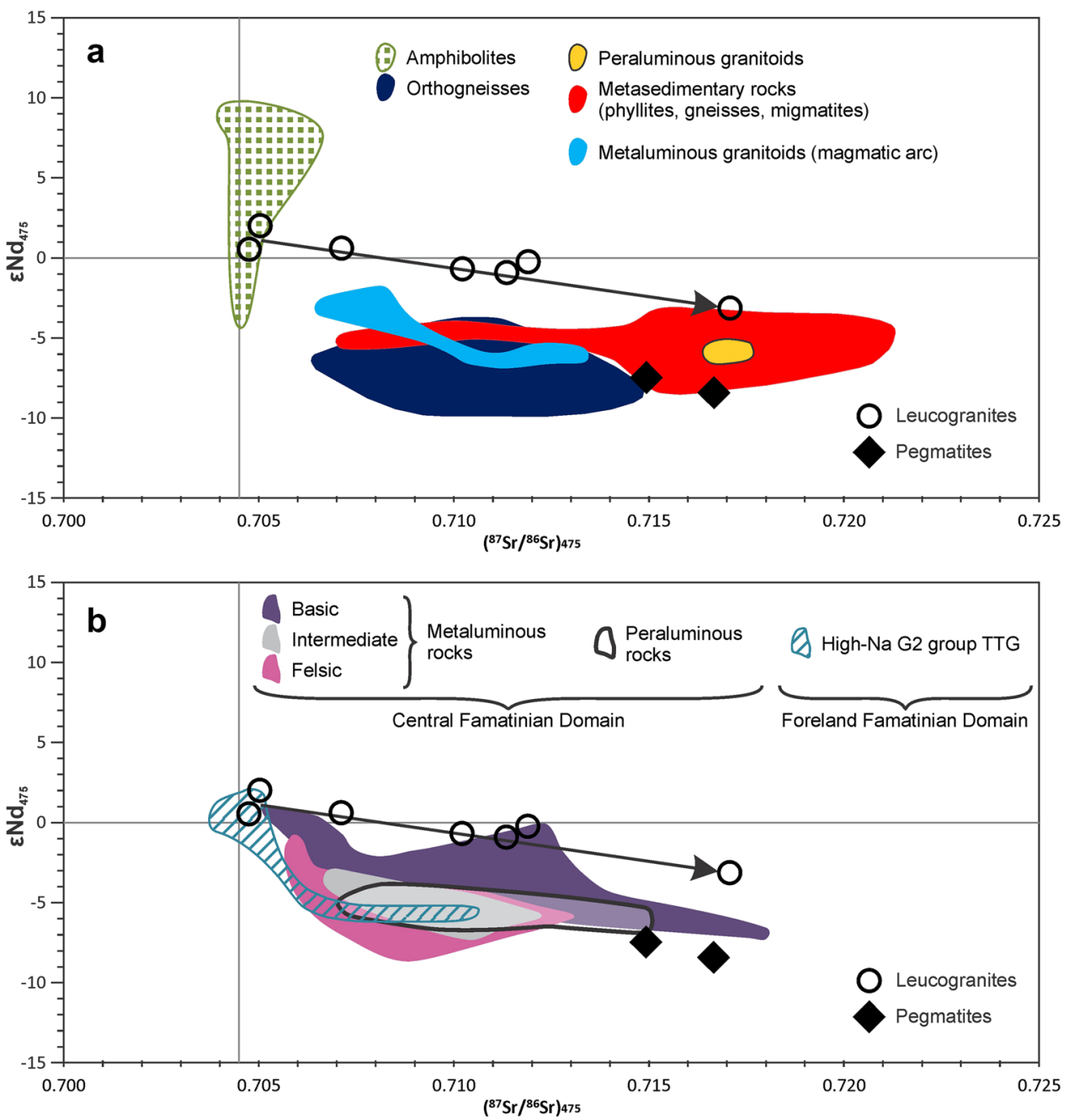

Fig. 5 Diagram showing initial ${ }^{87} \mathrm{Sr} /{ }^{86} \mathrm{Sr}_{(\mathrm{t})}$ vs $\varepsilon_{\mathrm{Nd}(\mathrm{t})}$ for the leucogranites (open circles) and granitic pegmatites (filled diamonds) from the CPF (data from this work), plotted together with Pampean and Famatinian rocks. All data were recalculated at $475 \mathrm{Ma}$, corresponding to the crystallization age of the leucogranites and pegmatites (Demartis et al. 2017). The arrow indicates the linear trend of increasing ${ }^{87} \mathrm{Sr} /{ }^{86} \mathrm{Sr}$ and decreasing $\varepsilon_{\mathrm{Nd}}$ for leucogranite samples. a Comparison between own data and several pre-Famatinian rock types from the Sierras de Córdoba (data summarized in Table 3). Data sources are from: Rapela et al. (1998a) and Steenken et al. (2011) for amphibolites; Rapela et al. (1998a) and Escayola et al. (2007) for orthogneisses; Rapela et al. (1998a) and Iannizzotto et al. (2013) for metaluminous granitoids; Rapela et al. (1998a) for peraluminous granitoids;

\section{Fractional crystallization}

The bivariate diagrams shown in previous sections (Fig. 3) suggest fractional crystallization processes among the leucogranite samples. A group of three samples $(19,100$ and 118) shows the highest contents of $\mathrm{Eu}, \mathrm{Ba}$ and $\mathrm{Sr}$ with a broad positive correlation between these elements. Since feldspars, and mostly plagioclase, have high partition coefficients for these elements (Philpotts and Schnetzler 1970;
Rapela et al. (1998a), Escayola et al. (2007), Drobe et al. (2011), Steenken et al. (2011) and Iannizzotto et al. (2013) for metasedimentary rocks. b Comparison between own data and Famatinian-aged igneous rocks from the different domains of the Famatinian orogen (Rapela et al. 2018). Data sources are from: Pankhurst et al. (1998), Pascua (1998), Fanning et al. (2004), Dahlquist et al. (2007, 2008, 2012), Casquet et al. (2012), Otamendi et al. (2012) and Alasino et al. (2014, 2016) for mafic, intermediate and felsic metaluminous and peraluminous igneous rocks from the Central Famatinian Domain; Rapela et al. (1998a) for the high-Na G2 group TTG from the Foreland Famatinian Domain (data compilation taken from Rapela et al. 2018)

Bacon and Druitt 1988), the positive correlation of these elements in leucogranites (Fig. 3a, b) and the presence of plagioclase crystals coexisting with residual melt infilling microfractures in some leucogranite samples (Demartis et al. 2017) support the fractionation of this mineral.

Trends among other trace elements, such as REE, $\mathrm{Y}$ and Th, suggest fractionation of minerals hosting these elements. The trends displaying increasing $(\mathrm{La} / \mathrm{Yb})_{\mathrm{N}}$ ratios and total REE contents with increasing Y (samples 19 and 100; 


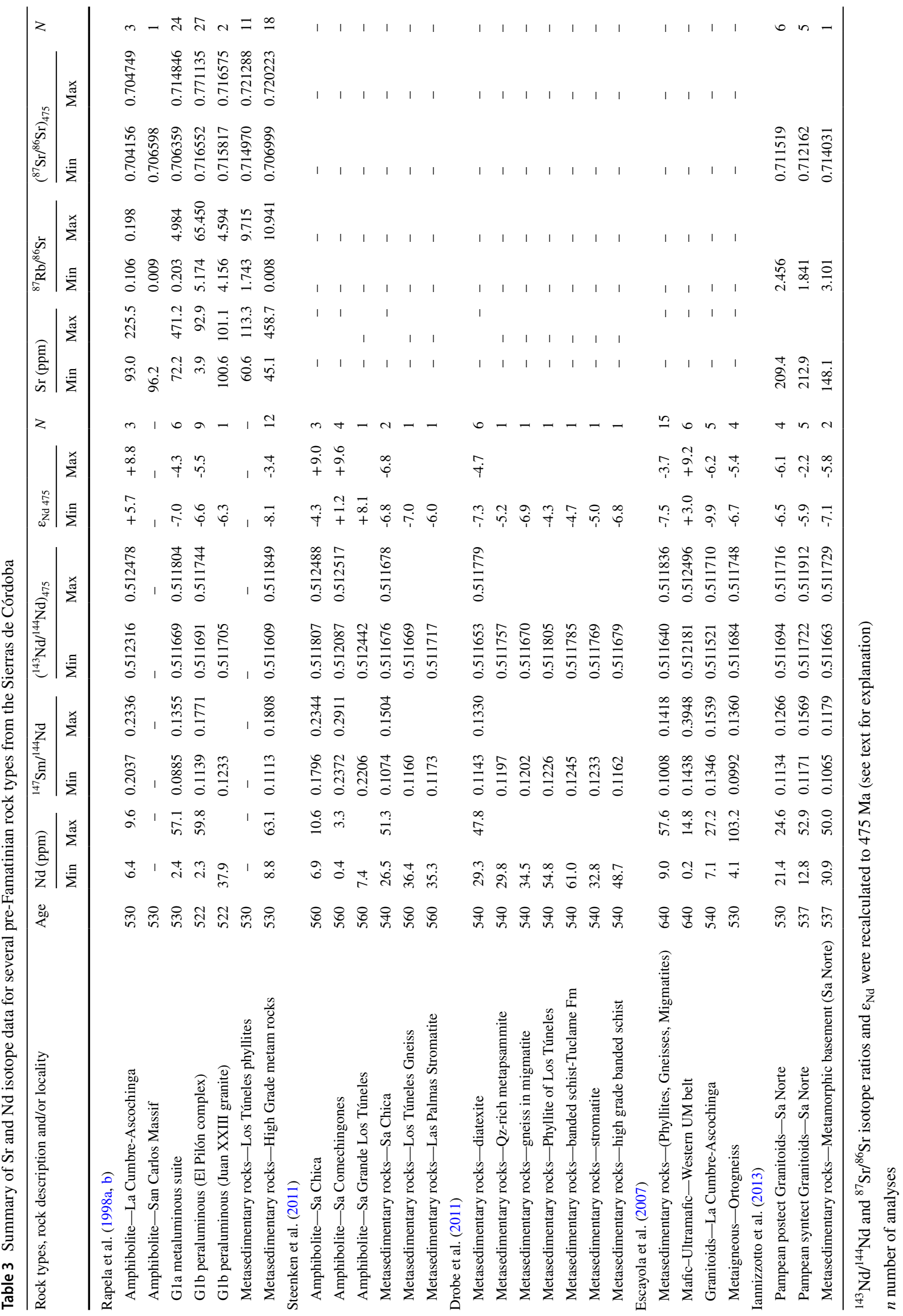



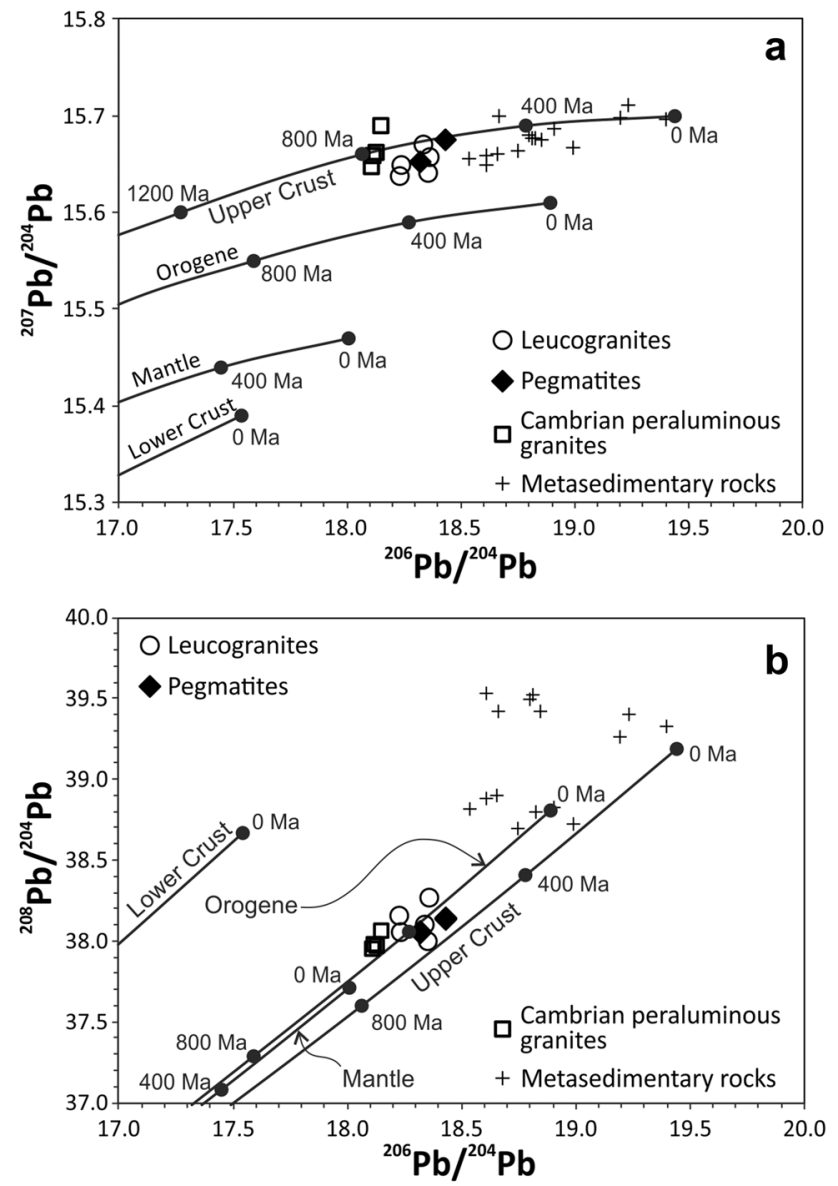

Fig. 6 Variations of the a ${ }^{207} \mathrm{~Pb} /{ }^{204} \mathrm{~Pb}$ vs ${ }^{206} \mathrm{~Pb} /{ }^{204} \mathrm{~Pb}$, and b ${ }^{208} \mathrm{~Pb} /{ }^{204} \mathrm{~Pb}$ vs ${ }^{206} \mathrm{~Pb} /{ }^{204} \mathrm{~Pb}$ isotope ratios for the leached K-feldspars of the leucogranites and granitic pegmatites from the CPF. Crosses and open rectangles represent the $\mathrm{Pb}$ isotopic compositions of metasedimentary rocks (Drobe et al. 2011) and feldspars from Cambrian peraluminous granites (Schwartz and Gromet 2004) of the Sierras de Córdoba. Growth curves for different reservoirs in the earth (upper and lower crust, mantle and orogene; Zartman and Doe 1981) are also shown for reference

Fig. 3d, e) indicate that both monazite and xenotime were fractionated. Monazites from granites and pegmatites have $\mathrm{ThO}_{2}$ contents as high as 10 and $22 \%$ (Zhu and O'Nions 1999; Cesbron 1989). Among our leucogranite samples, the good correlation between Th and total REE contents (Fig. 3f), as well as $(\mathrm{La} / \mathrm{Yb})_{\mathrm{N}}$ ratios, reinforces the hypothesis of monazite fractionation. Moreover, the high HREE and $\mathrm{Y}$ contents in samples 98 and 118 point to the fractionation of garnet, which was been described as an accessory mineral. In summary, the trace element abundances among the leucogranite samples support the importance of crystal fractionation processes.

A broadly good correlation is also observed between leucogranite samples with the lowest degree of fractionation (i.e., high $\mathrm{Sr}, \mathrm{Ba}, \mathrm{Eu}$, total REE, $\mathrm{Y}$ and Th contents and high
Table 4 Whole rock major and trace element compositions of amphibolites from the Sierras de Comechingones

\begin{tabular}{|c|c|c|c|c|c|}
\hline & JOR01 & 551 & 553 & 554 & 562 \\
\hline \multicolumn{6}{|c|}{ Major elements (wt\%) } \\
\hline $\mathrm{SiO}_{2}$ & 48.06 & 47.24 & 47.89 & 46.39 & 48.01 \\
\hline $\mathrm{TiO}_{2}$ & 2.11 & 2.49 & 1.77 & 1.04 & 2.38 \\
\hline $\mathrm{Al}_{2} \mathrm{O}_{3}$ & 14.29 & 14.19 & 16.36 & 15.52 & 15.84 \\
\hline $\mathrm{Fe}_{2} \mathrm{O}_{3(\mathrm{~T})}$ & 14.29 & 14.06 & 10.06 & 9.70 & 10.93 \\
\hline $\mathrm{MnO}$ & 0.21 & 0.20 & 0.16 & 0.16 & 0.17 \\
\hline $\mathrm{MgO}$ & 6.64 & 5.07 & 5.57 & 9.19 & 5.37 \\
\hline $\mathrm{CaO}$ & 9.92 & 11.43 & 13.73 & 13.34 & 11.38 \\
\hline $\mathrm{Na}_{2} \mathrm{O}$ & 2.56 & 2.80 & 2.44 & 1.84 & 3.37 \\
\hline $\mathrm{K}_{2} \mathrm{O}$ & 0.57 & 0.68 & 0.54 & 0.42 & 0.55 \\
\hline $\mathrm{P}_{2} \mathrm{O}_{5}$ & 0.16 & 0.28 & 0.23 & 0.08 & 0.35 \\
\hline LOI & 1.38 & 1.60 & 1.23 & 2.20 & 1.49 \\
\hline Total & 99.9 & 100.04 & 99.98 & 99.88 & 99.84 \\
\hline \multicolumn{6}{|c|}{ Trace elements (ppm) } \\
\hline $\mathrm{Ga}$ & 17 & 18 & 10 & 6 & 18 \\
\hline $\mathrm{Rb}$ & 3 & 11 & 5 & 12 & 5 \\
\hline $\mathrm{Sr}$ & 117 & 260 & 306 & 150 & 317 \\
\hline Y & 47 & 38 & 28 & 25 & 38 \\
\hline $\mathrm{Zr}$ & 142 & 182 & 144 & 65 & 225 \\
\hline $\mathrm{Nb}$ & 6 & 15 & 16 & 4 & 18 \\
\hline $\mathrm{Ba}$ & 33 & 130 & 106 & 46 & 70 \\
\hline $\mathrm{La}$ & 2 & 20 & 6 & 14 & 10 \\
\hline $\mathrm{Ce}$ & 23 & 31 & 14 & 18 & 29 \\
\hline $\mathrm{Nd}$ & 14 & b.d.l & 15 & 10 & b.d.l \\
\hline $\mathrm{Pb}$ & b.d.1 & b.d.l & 1 & 2 & 0 \\
\hline Th & b.d.l & 2 & 3 & 1 & 1 \\
\hline $\mathrm{U}$ & 3 & 1 & b.d.l & 4 & 2 \\
\hline $\mathrm{Co}$ & 159 & 165 & 239 & 202 & 300 \\
\hline $\mathrm{Cr}$ & 113 & 71 & 95 & 385 & 156 \\
\hline $\mathrm{Cu}$ & 58 & 56 & 43 & 96 & 59 \\
\hline $\mathrm{Ni}$ & 70 & 53 & 67 & 203 & 110 \\
\hline $\mathrm{Sc}$ & 39 & 36 & 35 & 42 & 32 \\
\hline $\mathrm{V}$ & 405 & 351 & 270 & 210 & 300 \\
\hline $\mathrm{Zn}$ & 109 & 103 & 68 & 63 & 79 \\
\hline
\end{tabular}

LOI loss of ignition, b.d.l. below detection limit

${ }^{\mathrm{a}} \mathrm{ASI}$ (Aluminum saturation index $)=[\mathrm{Al} /(\mathrm{Na}+\mathrm{K}+\mathrm{Ca})]_{\text {molar }}$

$(\mathrm{La} / \mathrm{Yb})_{\mathrm{N}}$ ratios) and the highly primitive isotopic character (unradiogenic initial ${ }^{87} \mathrm{Sr} /{ }^{86} \mathrm{Sr}$ ratios and radiogenic $\varepsilon_{\mathrm{Nd}}$ values). Samples with crustal isotopic signatures (radiogenic ${ }^{87} \mathrm{Sr} /{ }^{86} \mathrm{Sr}$ and unradiogenic $\varepsilon_{\mathrm{Nd}}$ ) also coincide with the most fractionated ones. These observations argue for combined processes including fractional crystallization and contamination/assimilation of crustal rocks, as will be shown in the next sections.

Positive Eu anomalies are generally found in poorly to moderately evolved pegmatites, such as the Comechingones field pegmatites, since K-feldspar, a major constituent of 
pegmatites, may easily accommodate $\mathrm{Eu}^{2+}$ at the alkali site. With fractionation of mainly K-feldspar, Eu is progressively consumed and positive Eu anomalies tend to decrease (Larsen 2002). Prominent positive Eu anomalies originate through accumulation of feldspar or through retention of feldspar during fractionation of LREE- and HREE-enriched minerals.

\section{Crustal materials: assimilation and fractional crystallization (AFC) processes}

Unlike the leucogranites, the pegmatites display radiogenic initial ${ }^{87} \mathrm{Sr} /{ }^{86} \mathrm{Sr}$ ratios and unradiogenic $\varepsilon_{\mathrm{Nd}}$ values, indicating an almost completely crustal derivation. When plotted in the initial ${ }^{87} \mathrm{Sr} /{ }^{86} \mathrm{Sr}$ ratios vs. initial $\varepsilon_{\mathrm{Nd}}$ values diagram (Fig. 5a), pegmatite samples overlap with the available isotopic compositions for metasedimentary rocks (schists, phyllites, paragneisses and migmatites) from the Sierras de Córdoba, suggesting a derivation from these crustal rocks.

The radiogenic initial ${ }^{87} \mathrm{Sr} /{ }^{86} \mathrm{Sr}$ ratios and the unradiogenic initial $\varepsilon_{\mathrm{Nd}}$ values of some leucogranite samples (Fig. 5) also indicate that crustal materials have been at least partly involved in the generation of these melts. The metasedimentary rocks of the Sierras de Córdoba show ${ }^{87} \mathrm{Sr}^{86} \mathrm{Sr}_{(475)}$ ratios and $\varepsilon_{\mathrm{Nd}(475)}$ values that range from 0.7070 to 0.7213 (most data range between 0.7140 and 0.7213 ) and from -3.4 to -8.1 , respectively (original isotopic compositions from Rapela et al. 1998a; Escayola et al. 2007; Steenken et al. 2010; Drobe et al. 2011, recalculated to the age of the leucogranites; Table 3). The most evolved leucogranite sample (sample 133) shows an initial isotopic composition close to the range shown by the metasedimentary rocks of the Sierras de Córdoba (Table 2), indicating that these rocks were involved in the evolution of the leucogranite melts.

The radiogenic initial ${ }^{87} \mathrm{Sr} /{ }^{86} \mathrm{Sr}$ ratios and the unradiogenic initial $\varepsilon_{\mathrm{Nd}}$ values of some leucogranite samples lead us to propose a combined assimilation and fractional crystallization process (AFC) as plausible processes that could explain the element and isotope compositions of the leucogranites. To test both, fractionation and crustal contamination, an AFC model was performed using the DePaolo (1981) equations. Estimating the degree of contamination by AFC processes (e.g. DePaolo 1981) depends critically on the model specific variables and the composition of the contaminant. From the trend of the $\mathrm{Nd}$ and $\mathrm{Sr}$ isotope data, it is apparent that the contaminant must have rather radiogenic $\mathrm{Sr}$ but unradiogenic $\mathrm{Nd}$ isotopic compositions, in which the composition of the contaminant is $\varepsilon_{\mathrm{Nd}} \leq-3$ and ${ }^{87} \mathrm{Sr} /{ }^{86} \mathrm{Sr} \geq 0.717$. According to the available isotopic data, the Pampean migmatites, high-grade gneisses and schists from the Sierras de Córdoba show these isotopic compositions (recalculated to $475 \mathrm{Ma}$; Fig. 5a). The involvement of these rocks in the origin of the leucogranites was suggested in an earlier contribution (Demartis et al. 2017), in which strong similarities in the age distribution patterns between the inherited zircons from leucogranites and detrital zircons from the Pampean metasedimentary rocks were reported. In the ${ }^{207} \mathrm{~Pb} /{ }^{204} \mathrm{~Pb}$ vs. ${ }^{206} \mathrm{~Pb} /{ }^{204} \mathrm{~Pb}$ diagram (Fig. 6a), the metasedimentary rocks (Drobe et al. 2011) and feldspars from the Cambrian peraluminous granites (Schwartz and Gromet 2004) of the Sierras de Córdoba plot close to the upper crust and orogene growth curves (Fig. 6a, b), as well as leucogranite and pegmatite feldspars analyzed in this study, pointing out that the metasedimentary rocks of the Pampean metamorphic belt were involved in the melting and assimilation processes to generate the leucogranites and pegmatites.

Assuming that the leucogranites owe their radiogenic $\mathrm{Sr}$ and unradiogenic $\mathrm{Nd}$ isotope composition to assimilation of the metasedimentary rocks from the Pampean metamorphic belt, a high degree of assimilation is necessary. In addition, the ratio of mass assimilated to mass fractionated must be set at a rather low value $(r \leq 0.3)$ because the leucogranites are highly fractionated rocks and large masses of assimilated material is thus precluded.

The bulk partition coefficient $D$ was calculated from the equation $D=\sum K d_{i} X_{i}$, where $K d_{i}$ is the partition coefficient of the element between mineral $i$ and the melt, and $X_{i}$ is the proportion of the mineral $i$ in the crystallizing solid. There is no field evidence of rocks that represent cumulates crystallized from the original melt, thus $D$ cannot be constrained by direct observations of rocks in the study area. Nonetheless, petrographic descriptions and geochemical data indicated the fractionation of plagioclase and monazite. Bulk partition coefficients $(D)$ of 2 and 1.5 for $\mathrm{Sr}$ and $\mathrm{Nd}$, respectively, are suitable for a fractionating solid composed by plagioclase, quartz and some other accessory phases, such as monazite and xenotime (Philpotts and Schnetzler 1970; Schnetzler and Philpotts 1970; Stepanov et al. 2012). The rest of the input parameters needed for the AFC models, such as isotope ratios and $\mathrm{Sr}$ and $\mathrm{Nd}$ contents of the original magma and the assimilated wallrock, were constrained based upon the available isotope data (Table 3) for Pampean amphibolites and metasedimentary rocks, respectively.

Based on the above discussed parameters (isotope ratios and $\mathrm{Sr}$ and $\mathrm{Nd}$ contents of the original magma and the assimilated wallrock, bulk partition coefficients, and the ratio of mass assimilated to mass fractionated), different AFC curves were tested. A spectrum of solutions limited by the two curves shown in Fig. 7 were found to explain the isotope compositions of the leucogranites. The final parameters used to construct these curves are summarized in Table 5 and briefly shown in Fig. 7. Although there is some uncertainty in some parameter, such as the chosen bulk partition coefficients for $\mathrm{Sr}$ and $\mathrm{Nd}$ which can only be qualitatively 
assessed, the most contaminated sample with $2.1 \mathrm{ppm} \mathrm{Nd}$ $\left({ }^{143} \mathrm{Nd} /{ }^{144} \mathrm{Nd}\right.$ : 0.511866$)$ and $41 \mathrm{ppm} \mathrm{Sr}\left({ }^{87} \mathrm{Sr} /{ }^{86} \mathrm{Sr}: 0.71708\right)$ corresponds to approximately modelled $\mathrm{Nd}\left({ }^{143} \mathrm{Nd} /{ }^{144} \mathrm{Nd}\right.$ : $0.511846)$ and $\mathrm{Sr}\left({ }^{87} \mathrm{Sr} /{ }^{86} \mathrm{Sr}\right.$ : 0.71702) abundances of 14 and $39 \mathrm{ppm}$, which seems to be a reasonably good fit (Fig. 7). This also corresponds to $\mathrm{F} \sim 0.16$ (remaining fraction of the original melt, in this case $16 \%$ ) for the most contaminated sample. Low melt fractions are typical for highly evolved leucogranites. For a more extreme isotope composition of the contaminant and/or higher $r$-values, the amount of assimilated material is smaller. In summary, the linear trend and the large variation in the isotope compositions of the leucogranites are best constrained by assuming AFC processes with remaining melt fractions between $\sim 0.15$ and 0.95 (Fig. 7).

\section{Leucogranites: anomalous isotopic compositions in the Famatinian orogen}

In the continental crust, magmas and rocks of different origins (mantle vs crustal) are usually involved in processes like magma mixing, contamination, assimilation, etc., which lead

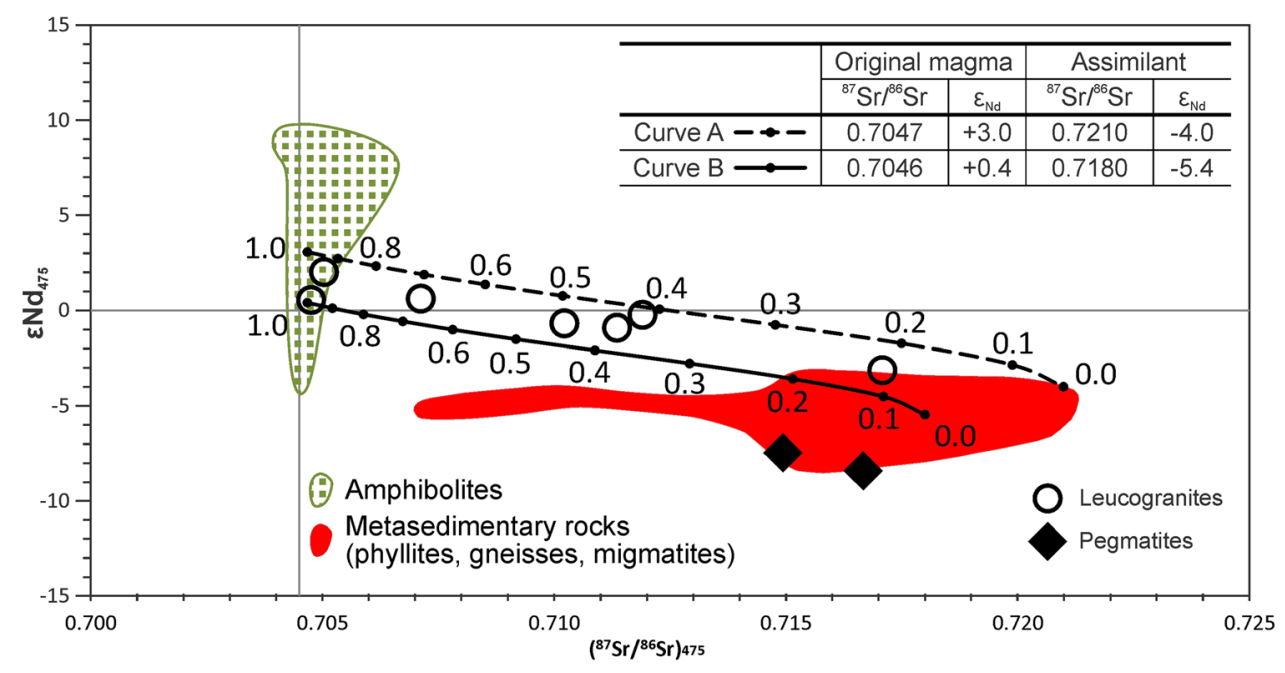

Fig. 7 Initial $\varepsilon_{\mathrm{Nd}}$ vs. initial ${ }^{87} \mathrm{Sr} /{ }^{86} \mathrm{Sr}$ diagram for the leucogranites and granitic pegmatites from the CPF (recalculated at an age of $475 \mathrm{Ma}$; Demartis et al. 2017), showing the AFC curves. Tick marks represent $F$ values (DePaolo 1981). Parameters used to perform the models are summarized in Table 5. Compositional fields of pre-Fam- atinian rocks from the Sierras de Córdoba are the same as in Fig. 4, and are taken from: Rapela et al. (1998a) and Steenken et al. (2011) for amphibolites; and Rapela et al. (1998a), Escayola et al. (2007), Drobe et al. (2011), Steenken et al. (2011) and Iannizzotto et al. (2013) for metasedimentary rocks (data summarized in Table 3)
Table 5 Parameters used to model AFC processes for the origin of leucogranites

\begin{tabular}{llll}
\hline & & ${ }^{87} \mathrm{Sr} /{ }^{86} \mathrm{Sr}$ & ${ }^{143} \mathrm{Nd} /{ }^{144} \mathrm{Nd}\left[\varepsilon_{\mathrm{Nd}}\right]$ \\
\hline Concentration of the element in the original magma $\left(C_{m}^{0}\right)$ & & $177 \mathrm{ppm}$ & $30 \mathrm{ppm}$ \\
Isotope ratio in the original magma $\left(\epsilon_{m}^{0}\right)$ & Curve A $^{\mathrm{a}}$ & 0.7047 & $0.512180[+3.0]$ \\
& Curve B $^{\mathrm{a}}$ & 0.7046 & $0.512046[+0.4]$ \\
Concentration of the element in the assimilated wallrock & & $149 \mathrm{ppm}$ & $32 \mathrm{ppm}$ \\
Isotope ratio in the assimilated wallrock $\left(\epsilon_{a}\right)$ & Curve A $^{\mathrm{a}}$ & 0.7210 & $0.511821[-4.0]$ \\
& Curve B $^{\mathrm{a}}$ & 0.7180 & $0.511750[-5.4]$ \\
Bulk solid/liquid partition coefficient $(D)$ & & 2.0 & 1.5 \\
Assimilation to Fractional Crystallization ratio $(r)$ & & 0.3 & \\
Age (in Ma) & & 475 & \\
\hline
\end{tabular}

The following equations taken from DePaolo (1981) were used for the AFC models: $\epsilon_{m}=\epsilon_{m}^{0}+\left(\epsilon_{a}-\epsilon_{m}^{0}\right)\left(1-\frac{C_{m}^{0}}{C_{m}} F^{-Z}\right)$ and $F^{-Z}=F^{\left(-\frac{r-1+D}{r-1}\right)}$

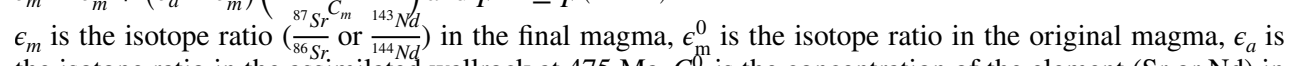
the isotope ratio in the assimilated wallrock at $475 \mathrm{Ma}, C_{m}^{0}$ is the concentration of the element ( $\mathrm{Sr}$ or $\mathrm{Nd}$ ) in the original magma, $C_{m}$ is the concentration of the element in the final magma, $F$ is the remaining magma fraction, $r$ is the assimilation to crystallization ratio, $D$ is the bulk solid/liquid partition coefficient for the element ( $\mathrm{Sr}$ or $\mathrm{Nd}$ ) between the crystallizing phase and the magma

${ }^{\mathrm{a} C}$ Curves A and B refer to AFC curves drawn in Fig. 6 
to negative arrays in the ${ }^{87} \mathrm{Sr} /{ }^{86} \mathrm{Sr}$ vs. $\varepsilon_{\mathrm{Nd}}$ diagram (Carter et al. 1978; McCulloch and Chappell 1982; Hildreth et al. 1991; Davidson and de Silva 1992; Ort et al. 1996; Healy et al. 2004; Troll et al. 2005; Wang et al. 2016). These arrays are the result of melting of mixed sources with contrasting isotope compositions in orogenic contexts (McCulloch and Chappell 1982; Chappell and White 1992; Collins 1996), or hybridization/contamination of mantle- or lower crustderived melts with crustal rocks having heterogeneous isotopic compositions (Carter et al. 1978; Hildreth et al. 1991; Davidson and de Silva 1992; Ort et al. 1996; Healy et al. 2004; Troll et al. 2005; Wang et al. 2016).

When plotted together in the $\varepsilon_{\mathrm{Nd}}{ }^{\mathrm{vs}}{ }^{87} \mathrm{Sr} /{ }^{86} \mathrm{Sr}$ diagram (Fig. 5b), the igneous rocks of Famatinian age that crop out in the Sierras Pampeanas show isotopic compositions with a wide spread in both initial ${ }^{87} \mathrm{Sr} /{ }^{86} \mathrm{Sr}$ ratios and $\varepsilon_{\mathrm{Nd}}$ values, the great majority of which range between 0.7059 and 0.7187 , and +0.3 and -8.7 , respectively (Rapela et al. 1998a, 2018; Llambías et al. 1998; Pankhurst et al. 1998, 2000; Otamendi et al. 2012; Dahlquist et al. 2008, 2013; Grosse et al. 2011; Ducea et al. 2017; Alasino et al. 2016; Walker et al. 2015, and references therein). The whole dataset of Famatinian-aged igneous rocks resembles a concave upwards hyperbola with contrasting endmembers, suggesting that mixing, hybridization and/or contamination processes involving mantle- and crustal-derived materials have taken place. Such processes have been proposed by several authors for the Famatinian orogen (Casquet et al. 2012; Cristofolini et al. 2012; Walker et al. 2015; Otamendi et al. 2017; Suzaño et al. 2017; Rapela et al. 2018; Weinberg et al. 2018; Morosini et al. 2019; Camiletti et al. 2020).

From the comparison between the whole dataset of the Famatinian-aged igneous rocks and the linear trend defined for the leucogranites samples in the ${ }^{87} \mathrm{Sr} /{ }^{86} \mathrm{Sr}$ vs. $\varepsilon_{\mathrm{Nd}}$ diagram (Fig. 5b), two observations can be pointed out. First, the most primitive leucogranite samples show less radiogenic ${ }^{87} \mathrm{Sr} /{ }^{86} \mathrm{Sr}$ initial ratios and more radiogenic $\varepsilon_{\mathrm{Nd}}$ values than almost any other rock, except for the tonalitetrondhjemite-granodiorites from the Sierras de Córdoba and a few basic rocks from the Sierra de Valle Fértil and the Famatina system. Second, the rest of the leucogranite samples that define the linear trend plot above the compositions available for the Famatinian igneous rocks of the Sierras Pampeanas (Fig. 5b), resulting in magmas with anomalous isotopic compositions in the context of the Famatinian orogen. According to the previously discussed models, this particular linear trend and the anomalous isotopic compositions of the leucogranites are here proposed to be explained by the following sequence of events: (1) the partial melting of country rocks with primitive isotopic compositions (i.e. amphibolites) in water-fluxed conditions generating unexposed granodiorite melts, and (2) evolution of these granodioritic melts by fractional crystallization towards the compositions of the leucogranites, involving the assimilation of crustal materials.

\section{Water-fluxed melting and the role of the Guacha Corral shear zone}

Another topic to be addressed is the melting conditions of amphibolites in the context of the Famatinian orogeny and the local geological setting. As previously discussed, dehydration melting of amphibolites would have required high $\mathrm{P}-\mathrm{T}$ conditions giving rise to melts with tonalitic compositions. On the contrary, water-fluxed melting is expected to be a more plausible alternative not only for the compositions of the resulting melts but also for the melting conditions at which it took place. According to geodynamic models, the Sierras de Córdoba have been located in the foreland of the Famatinian orogen, almost $200 \mathrm{~km}$ away from the arc (Rapela et al. 2018; Weinberg et al. 2018). Extensive dehydration melting of amphibolitic rocks would have required a heat transfer that would have also caused a much more extensive melting of the metamorphic basement of the region during Famatinian times. Instead, water-fluxed melting could have been limited to a much more restricted zone into which fluids have migrated to. If this is true, the origin of fluids and their migration pathways must be constrained.

Since there are no outcrops of migmatites of Famatinian age in the CPF, the origin of fluids and the specific metamorphic reactions are difficult to assess; however, the pathways for fluid migration can be inferred from the geological framework. The structural and microstructural evidence pointing out to a continuous deformation from the submagmatic to subsolidus conditions, along with the coincidence between the orientation of the main structures and the sense of shearing of the leucogranites, pegmatites and host mylonites in the CPF, indicates that the leucogranites and pegmatites were emplaced syn-kinematically with the main deformational event of the Guacha Corral shear zone (Demartis et al. 2011, 2017). As was commented in previous sections, this shear zone is a first-order crustal-scale structure that juxtaposed terranes with different metamorphic histories, and with up to $10 \mathrm{~km}$ width in its thickest portion. Such a structure has probably exerted a crucial role in the migration of fluids from the enclosing metamorphic terranes into amphibolitic and metasedimentary rocks that were at suprasolidus conditions, thus triggering their waterfluxed melting.

Weinberg and Hasalova (2015) and Butler et al. (1997) summarized and emphasized the effects of active shear zones and thrusts in the migration of regional fluids and water-fluxed melting of rocks that were at or below their solidus conditions. For example, the Karakoram shear zone, NW India, was deemed as a major structure into which fluids 
migrated due to local and regional pressure gradients, triggering water-fluxed melting on metasedimentary protoliths and calc-alkaline magmatic rocks (Reichardt et al. 2010; Weinberg and Mark 2008; Reichardt and Weinberg 2012). Melting processes were coeval with folding and shearing of the Karakoram shear zone producing dike swarms of leucogranites parallel to the shear plane, interpreted as a transfer zone that sourced the Karakoram batholith in higher structural level (Reichardt and Weinberg 2012).

Similarly, we infer that the Guacha Corral shear zone could have acted as an efficient pathway for fluids to migrate, thus triggering water-fluxed melting and generating the leucogranite and pegmatite melts. Moreover, numerous pegmatitic and hydrothermal quartz veins extensively crop out within the Guacha Corral shear zone (Demartis et al. 2010; Morteani et al. 2016; unpublished data). The occurrence of these veins is almost restricted to the shear zone and they are practically absent outside it, thus suggesting that the fluid migration was enhanced by the deformation of this crustalscale structure. Additionally, as was briefly summarized in previous sections, the deformation along the Guacha Corral shear zone has also efficiently contributed magmas to flow towards higher crustal levels by generating local and temporal spaces in such a contractional deformational setting (Demartis et al. 2011). These ideas suggest a close relationship among deformation, anatexis, magma generation and transport through such a crustal-scale structure.

\section{Summary and conclusion}

Field relationships, petrographic observations and major, trace element and isotope geochemistry have been complemented to assess the origin of the leucogranites and pegmatites from the CPF in the Sierras Pampeanas of Córdoba, central Argentina. The leucogranites and pegmatites are strongly peraluminous with high $\mathrm{SiO}_{2}$ and alkali contents and low $\mathrm{CaO}, \mathrm{FeO}$ and $\mathrm{MgO}$ abundances. Strontium, $\mathrm{Nd}$ and $\mathrm{Pb}$ isotopic compositions (radiogenic initial ${ }^{87} \mathrm{Sr} /{ }^{86} \mathrm{Sr}$ and unradiogenic $\varepsilon_{\mathrm{Nd}}$ values) indicate that pegmatites were derived from partial melting of the metasedimentary protoliths. Unlike pegmatites, leucogranites display particular $\mathrm{Sr}$ and $\mathrm{Nd}$ isotopic compositions that define a linear trend from samples with primitive isotopic character (initial ${ }^{87} \mathrm{Sr} /{ }^{86} \mathrm{Sr}: \sim 0.7047$ and initial $\varepsilon_{\mathrm{Nd}}:+2.0$ ) to samples with inferred higher proportion of evolved crustal-derived materials (initial ${ }^{87} \mathrm{Sr} /{ }^{86} \mathrm{Sr}: \sim 0.7171$ and initial $\left.\varepsilon_{\mathrm{Nd}}:-3.1\right)$. This trend plots above the vast majority of the available isotopic compositions for different rock types from the Sierras de Córdoba, and overlaps with almost no other igneous rocks of Famatinian age. The primitive character of some leucogranites and the particular isotopic trend of all samples are here explained by the following evolutionary model. Water-fluxed melting of amphibolites gave rise to currently unexposed granodioritic melts that evolved by fractional crystallization reaching compositions close to that of the leucogranites. The assimilation of different amounts of crustal materials along with fractional crystallization (AFC) yielded leucogranite melts with particular isotope compositions.

According to the deformational context of the Guacha Corral shear zone in which the leucogranites and pegmatites were emplaced, we suggest that water-fluxed melting of the amphibolites and metasedimentary rocks was triggered by fluid migration from the surrounding rocks into this crustal-scale shear zone due to pressure gradients produced by deformation. This led to the generation and evolution of melts from which the leucogranites and pegmatites derived. As was previously stated, the continued deformation occurred in the Guacha Corral shear zone could also have promoted the movement of the melts through the crust. Thus, our findings obtained in this paper, along with previously published results, reinforce the idea of feedback relationships among deformation, anatexis, magma evolution and mass transfer throughout the crust, in the context of a crustal-scale shear zone, such as the Guacha Corral shear zone in the foreland of the Famatinian orogen.

Acknowledgements This work has been financially supported by grants PICT1754/16 (Agencia Nacional de Promoción Científica y Tecnológica, Argentina), PIP688 (Consejo Nacional de Investigaciones Científicas y Técnicas, Argentina) and PPI 18/C456 (Universidad Nacional de Río Cuarto). The authors want to thank the comprehensive and fruitful reviews of Roberto Weinberg, Sebastián Oriolo and Ulrich Riller that strongly contributed to improve the manuscript. M. Demartis wants to thank Mr. Peter Stutz (Universität Hamburg) for laboratory assistance during a research stay.

Funding This work has been financially supported by the National Agency for Scientific and Technological Promotion (Agencia Nacional de Promoción Científica y Tecnológica, Argentina), the National Scientific and Technical Research Council (Consejo Nacional de Investigaciones Científicas y Técnicas, Argentina) and the National University of Río Cuarto (Universidad Nacional de Río Cuarto, Argentina).

\section{Compliance with ethical standards}

Conflict of interest The authors do not have any conflicts of interest to declare.

\section{References}

Alasino PH, Casquet C, Larrovere MA, Pankhurst RJ, Galindo C, Dahlquist JA, Baldo EG, Rapela CW (2014) The evolution of a midcrustal thermal aureole at Cerro Toro, Sierra de Famatina, NW 
Argentina. Lithos 190-191:154-172. https://doi.org/10.1016/j. lithos.2013.12.006

Alasino PH, Casquet C, Pankhurst RJ, Rapela CW, Dahlquist JA, Galindo C, Larrovere MA, Recio C, Paterson SR, Colombo F, Baldo EG (2016) Mafic rocks of the Ordovician Famatinian magmatic arc (NW Argentina): new insights into the mantle contribution. Geol Soc Am Bull 128:1105-1120. https://doi.org/10.1130/ B31417.1

Andrade FRD, Möller P, Höhndorf A (1999) The Effect of Hydrothermal Alteration on the $\mathrm{Sr}$ and $\mathrm{Nd}$ Isotopic Signatures of the Barra do Itapirapuã Carbonatite, Southern Brazil. J Geol 107(2):177191. https://doi.org/10.1086/314339

Bacon CR, Druitt TH (1988) Compositional evolution of the zoned calcalkaline magma chamber of Mount-Mazama, Crater Lake, Oregon. Contrib Miner Petrol 98:224-256. https://doi.org/10.1007/ bf00402114

Barbarin B (1996) Genesis of the two main types of peraluminous granitoids. Geology 24(4):295-298. https://doi.org/10.1130/00917613(1996)024\%3c0295:gottmt\%3e2.3.co;2

Beard JS, Lofgren GE (1991) Dehydration melting and water-saturated melting of basaltic and andesitic greenstones and amphibolites at 1, 3, and 6.9 kb. J Petrol 32(2):365-401. https://doi.org/10.1093/ petrology/32.2.365

Boynton WV (1984) Cosmochemistry of the rare earth elements: Meteorite Studies. In: Henderson P (ed) Rare earth element geochemistry. Developments in Geochemistry. Elsevier, Amsterdam, pp 63-114. https://doi.org/10.1016/b978-0-444-42148-7.50008-3

Butler RWH, Harris NBW, Whittington AG (1997) Interactions between deformation, magmatism and hydrothermal activity during active crustal thickening: a field example from Nanga Parbat, Pakistan Himalayas. Mineral Mag 61(404):37-52. https ://doi.org/10.1180/minmag.1997.061.404.05

Camilletti G, Otamendi JE, Tibaldi A, Cristofolini E, Leisen M, Romero R, Barzola M (2020) Geology, petrology and geochronology of sierra Valle Fértil-La Huerta batholith: Implications for the construction of a middle-crust magmatic-arc section. J South Am Earth Sci 97:102423. https://doi.org/10.1016/j.jsame s.2019.102423

Carter SR, Evensen NM, Hamilton PJ, O’Nions RK (1978) Neodymium and strontium isotope evidence for crustal contamination of continental Volcanics. Science 202(4369):743-747. https://doi. org/10.1126/science.202.4369.743

Casquet C, Rapela CW, Pankhurst RJ, Baldo EG, Galindo C, Fanning CM, Dahlquist JA (2012) Fast sediment underplating and essentially coeval juvenile magmatism in the Ordovician margin of Gondwana, Western Sierras Pampeanas, Argentina. Gondwana Res 22:664-673. https://doi.org/10.1016/j.gr.2012.05.001

Casquet C, Dahlquist JA, Verdecchia SO, Baldo EG, Galindo C, Rapela CW, Pankhurst RJ, Morales MM, Murra JA, Fanning CM (2018) Review of the Cambrian Pampean orogeny of Argentina; a displaced orogeny formerly attached to the Saldania Belt of South Africa? Earth Sci Rev 177:209-225. https://doi.org/10.1016/j. earscirev.2017.11.013

Castro A (2014) The off-crust origin of granite batholiths. Geosci Front 5(1):63-75. https://doi.org/10.1016/j.gsf.2013.06.006

Černý P, Ercit TS (2005) The classification of granitic pegmatites revisited. Can Mineral 43(6):2005-2026. https://doi.org/10.2113/ gscanmin.43.6.2005

Cesbron FP (1989) Mineralogy of the Rare-Earth Elements. In: Möller P, Černý P, Saupé F (eds) Lanthanides, Tantalum and Niobium. Society for geology applied to mineral deposits, Special Publication No. 7. Springer, Berlin, Heidelberg, pp 3-26. https://doi. org/10.1007/978-3-642-87262-4_1

Chappell BW, White AJR (1974) Two contrasting granite types. Pac Geol 8:173-174
Chappell BW, White AJR (1992) I- and S-type granites in the Lachlan Fold Belt. Trans R Soc Edinb Earth Sci 83:1-26. https://doi. org/10.1017/S0263593300007720

Chappell BW, White AJR (2001) Two contrasting granite types: 25 years later. Aust J Earth Sci 48(4):489-499. https://doi.org/10.1 046/j.1440-0952.2001.00882.x

Clemens JD, Stevens G (2012) What controls chemical variation in granitic magmas? Lithos 134-135:317-329. https://doi. org/10.1016/j.lithos.2012.01.001

Clemens JD, Stevens G, Farina F (2011) The enigmatic sources of I-type granites: the peritectic connexion. Lithos 126(3-4):174181. https://doi.org/10.1016/j.lithos.2011.07.004

Collins WJ (1996) Lachlan fold belt granitoids: products of three-component mixing. Trans R Soc Edinb Earth Sci 87:171-181. https ://doi.org/10.1130/0-8137-2315-9.171

Cristofolini EA, Fagiano M, Pinotti LP (2008) Fábricas migmáticas y miloníticas: un análisis comparativo, norte de Sierra de Comechingones, Córdoba. XVII Congreso Geológico Argentino, 1334. San Salvador de Jujuy, Argentina

Cristofolini EA, Otamendi JE, Ducea MN, Pearson DM, Tibaldi AM, Baliani I (2012) Detrital zircon U-Pb ages of metasedimentary rocks from Sierra de Valle Fértil: Entrapment of Middle and Late Cambrian marine successions in the deep roots of the Early Ordovician Famatinian arc. J South Am Earth Sci 37:77-94. https://doi.org/10.1016/j.jsames.2012.02.001

Dahlquist JA, Galindo C, Pankhurst RJ, Rapela CW, Alasino PH, Saavedra J, Fanning CM (2007) Magmatic evolution of the Peñón Rosado granite: petrogenesis of garnet-bearing granitoids. Lithos 95(3-4):177-207. https://doi.org/10.1016/j.lithos.2006.07.010

Dahlquist JA, Pankhurst RJ, Rapela CW, Galindo C, Alasino P, Fanning CM, Saavedra J, Baldo E (2008) New SHRIMP U-Pb data from the Famatina complex: constraining Early-Mid Ordovician Famatinian magmatism in the Sierras Pampeanas, Argentina. Geol Acta 6:319-333. https://doi.org/10.1344/105.000000260

Dahlquist JA, Rapela CW, Pankhurst RJ, Fanning CM, Vervoort JD, Garret H, Baldo EG, Murra JA, Alasino P, Colombo F (2012) Age and magmatic evolution of the Famatinian granitic rocks of Sierra de Ancasti, Sierras Pampeanas, Argentina. J S Am Earth Sci 34:10-25. https://doi.org/10.1016/j.jsames.2011.07.006

Dahlquist JA, Pankhurst RJ, Gaschnig RM, Rapela CW, Casquet C, Alasino PH, Galindo C, Baldo E (2013) Hf and Nd isotopes in Early Ordovician to Early Carboniferous granites as monitors of crustal growth in the Proto-Andean margin of Gondwana. Gondwana Res 23:1617-1630. https://doi.org/10.1016/j. gr.2012.08.013

Davidson JP, de Silva SL (1992) Volcanic rocks from the Bolivian Altiplano: insights into crustal structure, contamination, and magma genesis in the central Andes. Geology 20(12):11271130. https://doi.org/10.1130/0091-7613(1992)020\%3c112 7:vrftba\%3e2.3.co;2

Demartis M, Coniglio JE, Pinotti LP, D`Eramo FJ, Agulleiro Insúa LA, Muñoz AA, Petrelli HA (2010) Fluid modelling of the pegmatites from the southern portion of the Comechingones field, Córdoba: new stable isotope data. $10^{\circ}$ Congreso de Mineralogía y Metalogenia, Río Cuarto. Actas: 171-178. ISBN: 978-987-1003-64-8

Demartis M, Pinotti LP, Coniglio JE, D’Eramo FJ, Tubía JM, Aragón E, Agulleiro Insúa LA (2011) Ascent and emplacement of pegmatitic melts in a major reverse shear zone (Sierras de Córdoba, Argentina). J Struct Geol 33(9):1334-1346. https://doi. org/10.1016/j.jsg.2011.06.008

Demartis M, Melgarejo JC, Colombo F, Alfonso P, Coniglio JE, Pinotti LP, D'Eramo FJ (2014) Extreme F activities in late pegmatitic events as a key factor for LILE and HFSE enrichment: the Ángel pegmatite, Central Argentina. Can Mineral 52(2):247-269. https ://doi.org/10.3749/canmin.52.2.247 
Demartis M, Jung S, Berndt J, Aragón E, Sato AM, Radice S, Maffini MN, Coniglio JE, Pinotti LP, D’Eramo FJ, Agulleiro Insúa LA (2017) Famatinian inner arc: Petrographical observations and geochronological constraints on pegmatites and leucogranites of the Comechingones pegmatitic field (Sierras de Córdoba, Argentina). J S Am Earth Sci 79:239-253. https://doi.org/10.1016/j. jsames.2017.08.010

DePaolo DJ (1981) Trace element and isotopic effects of combined wall rock assimilation and fractional crystallization. Earth Planet Sci Lett 53:189-202. https://doi.org/10.1016/0012-821X(81)90153-9

D'Eramo FJ, Pinotti LP, Tubía JM, Vegas N, Coniglio JE, Aranguren A, Tejero R, Gómez D (2006) Coalescence of lateral spreading magma ascending through dykes: a mechanism to form a granite canopy (El Hongo pluton, Sierras Pampeanas, Argentina). J Geol Soc Lond 163(5):881-892. https://doi.org/10.1144/0016-76490 5-060

D'Eramo FJ, Tubía JM, Pinotti LP, Vegas N, Coniglio JE, Demartis M, Aranguren A, Basei M (2013) Granite emplacement by crustal boudinage: example of the Calmayo and El Hongo plutons (Córdoba, Argentina). Terra Nova 25(5):423-430. https://doi. org/10.1111/ter.12053

D’Eramo FJ, Pinotti LP, Bonalumi A, Sfragulla J, Demartis M, Coniglio JE, Baldo EG (2014) El magmatismo Ordovícico en las Sierras Pampeanas de Córdoba. Martino RD, Guereschi AB (eds) Relatorio del XIX Congreso Geológico Argentino: Geología y Recursos Naturales de la provincia de Córdoba. Asociación Geológica Argentina, Part I, pp 233e254

Drobe M, López de Luchi M, Steenken A, Wemmer K, Naumann R, Frei R, Siegesmund S (2011) Geodynamic evolution of the Eastern Sierras Pampeanas (Central Argentina) based on geochemical, $\mathrm{Sm}-\mathrm{Nd}, \mathrm{Pb}-\mathrm{Pb}$ and SHRIMP data. Int J Earth Sci 100(2-3):631-657. https://doi.org/10.1007/s00531-010-0593-3

Ducea MN, Bergantz GW, Crowley JL, Otamendi JE (2017) Ultrafast magmatic buildup and diversification to produce continental crust during subduction. Geology. https://doi.org/10.1130/ G38726.1

Escayola MP, Pimentel MM, Armstrong R (2007) Neoproterozoic back arc basin: Sensitive high-resolution ion microprobe $\mathrm{U}-\mathrm{Pb}$ and $\mathrm{Sm}-\mathrm{Nd}$ isotopic evidence from the Eastern Pampean Ranges, Argentina. Geology 35(6):495. https://doi.org/10.1130/g2354 9a.1

Fagiano M (2007) Geología y Petrología del basamento cristalino de las Albahacas, sur de la Sierra de Comechingones, Córdoba. Dissertation, National University of Río Cuarto, Argentina

Fagiano M, Martino R (2004) Cinemática y petrología de la faja de cizalla Guacha Corral en el extremo austral de la sierra de Comechingones, Provincia de Córdoba. Rev de la Asociación Geol Argent Ser D 7:45-50

Fagiano M, Pinotti LP, Esparza AM (2004) Metamorfismo, deformación y magmatismo asociados en el tramo medio de la Sierra de Comechingones, provincia de Córdoba. VII Congreso de Mineralogía y Metalogenia, 315-320. Río Cuarto, Argentina

Fanning CM, Pankhurst RJ, Rapela CW, Baldo EG, Casquet C, Galindo C (2004) K-bentonites in the Argentine Precordillera contemporaneous with volcanism in the Famatinian arc. J Geol Soc Lond 161:747-756. https://doi.org/10.1144/0016-764903-130

Galliski M (1994) La Provincia Pegmatítica Pampeana. I: Tipología y distribución de sus distritos económicos. Rev de la Asociación Geol Argent 49:99-112

Grosse P, Bellos LI, de los Hoyos CR, Larrovere MA, Rossi JN, Toselli AJ (2011) Across-arc variation of the Famatinian magmatic arc (NW Argentina) exemplified by I-, S- and transitional I/S-type Early Ordovician granitoids of the Sierra de Velasco. J South Am Earth Sci 32:110-126. https://doi.org/10.1016/j.jsame s.2011.03.014
Healy B, Collins WJ, Richards SW (2004) A hybrid origin for Lachlan S-type granites: the Murrumbidgee Batholith example. Lithos 78(1-2):197-216. https://doi.org/10.1016/j.lithos.2004.04.047

Hildreth W, Halliday AN, Christiansen RL (1991) Isotopic and chemical evidence concerning the genesis and contamination of basaltic and rhyolitic magma beneath the Yellowstone Plateau Volcanic Field. J Petrol 32(1):63-138. https://doi.org/10.1093/petro $\log / 32.1 .63$

Hoernle K, Hauff F, Kokfelt TF, Haase K, Garbe-Schönberg D, Werner R (2011) On- and off-axis chemical heterogeneities along the South Atlantic Mid-Ocean Ridge $\left(5-11^{\circ} \mathrm{S}\right)$ : Shallow or deep recycling of ocean crust and/or intraplate volcanism? Earth Planet Sci Lett 306(1-2):86-97. https://doi.org/10.1016/j. eps1.2011.03.032

Iannizzotto NF, Rapela CW, Baldo EGA, Galindo C, Fanning CM, Pankhurst RJ (2013) The Sierra Norte-Ambargasta batholith: Late Ediacaran-Early Cambrian magmatism associated with Pampean transpressional tectonics. J South Am Earth Sci 42:127-143. https://doi.org/10.1016/j.jsames.2012.07.009

Jordan TE, Allmendiger RW (1986) The Sierras Pampeanas of Argentina: a modern analogue of Rocky Mountain foreland deformation. Am J Sci 286:737-764. https://doi.org/10.2475/ ajs.286.10.737

Kalsbeek F, Frei R (2006) The Mesoproterozoic Midsommers $\varnothing$ dolerites and associated high-silica intrusions, North Greenland: crustal melting, contamination and hydrothermal alteration. Contrib Miner Petrol 152(1):89-110. https://doi.org/10.1007/s0041 0-006-0096-1

Larsen RB (2002) The distribution of rare-earth elements in K-feldspar as an indicator of petrogenetic processes in granitic pegmatites: examples from two pegmatite fields in southern Norway. Can Mineral 40(1):137-152. https://doi.org/10.2113/gscan $\min .40 .1 .137$

Lee Y, Cho M (2013) Fluid-present disequilibrium melting in Neoarchean arc related migmatites of Daeijak Island, western Gyeonggi Massif, Korea. Lithos 179:249-262. https://doi. org/10.1016/j.lithos.2013.08.011

Lira R, Sfragulla J (2014) El magmatismo Devónico-Carbonífero: el batolito de Achala y plutones menores al norte del cerro Champaquí. In: Martino RD, Guereschi AB (eds) Relatorio del XIX Congreso Geológico Argentino: Geología y Recursos Naturales de la provincia de Córdoba. Asociación Geológica Argentina, part I, pp 293-347

Llambías EJ, Sato AM, Ortiz Suárez A, Prozzi C (1998) The granitoids of the Sierra de San Luis. In: Pankhurst RJ, Rapela CW (eds) The Proto-Andean Margin of Gondwana. Geological Society (London), vol 142, pp 325-341. https://doi.org/10.1144/gsl. sp.1998.142.01.16

López S, Castro A (2001) Determination of the fluid-absent solidus and supersolidus phase relationships of MORB-derived amphibolites in the range 4-14 kbar. Am Miner 86:1396-1403. https://doi. org/10.2138/am-2001-11-1208

Luais B, Duchêne S, de Sigoyer J (2001) Sm-Nd disequilibrium in high-pressure, low-temperature Himalayan and Alpine rocks. Tectonophysics 342(1-2):1-22. https://doi.org/10.1016/s0040 $-1951(01) 00154-8$

Martino R (2003) Las fajas de deformación dúctil de las Sierras Pampeanas de Córdoba: Una reseña general. Rev de la Asociación Geol Argent 58(4):549-571

Martino R, Kraemer D, Escayola P, Giambastiani M, Arnosio M (1995) Transecta de las Sierras Pampeanas de Córdoba a los $32^{\circ} 00^{\prime}$ LS. Rev de la Asociación Geol Argent 50:60-77

McCulloch MT, Chappell BW (1982) Nd isotopic characteristics of S- and I-type granites. Earth Planet Sci Lett 58(1):51-64. https ://doi.org/10.1016/0012-821x(82)90102-9 
Morosini A, Enriquez E, Pagano D, Orozco B, Ulacco J, Tibaldi A, Cristofolini E, Muñoz B, Ortiz Suárez A, Montenegro V, Sánchez E, Icazatti F, Gil R, Crespo E, Ramos G (2019) Las Cañas plutonic complex: geodynamic implications during the Famatinian magmatism in northeast of Sierra de San Luis, Argentina. J South Am Earth Sci 93:313-347. https://doi.org/10.1016/j.jsame s.2019.04.028

Morteani G, Eichinger F, Tarantola A, Müller A, Götze J, Sfragulla JA (2016) The synorogenic pegmatitic quartz veins of the Guacha Corral Shear zone (Sierra de Comechingones, Argentina): a textural, chemical, isotopic, cathodoluminescence and fluid inclusion study. Geochemistry 76(3):391-404. https://doi. org/10.1016/j.chemer.2015.09.001

Murra JA, Casquet C, Locati F, Galindo C, Baldo EG, Pankhurst RJ, Rapela CW (2016) Isotope (Sr, C) and U-Pb SHRIMP zircon geochronology of marble-bearing sedimentary series in the Eastern Sierras Pampeanas, Argentina. Constraining the SW Gondwana margin in Ediacaran to early Cambrian times. Precambr Res 281:602-617. https://doi.org/10.1016/j.preca mres.2016.06.012

Ort MH, Coira BL, Mazzoni MM (1996) Generation of a crust-mantle magma mixture: magma sources and contamination at Cerro Panizos, central Andes. Contrib Miner Petrol 123(3):308-322. https://doi.org/10.1007/s004100050158

Otamendi JE, Patiño Douce A, Demichelis A (1999) Amphibolite to granulite transition in aluminous greywackes from the Sierra de Comechingones, Argentina. J Metamorph Geol 17:415-434. https://doi.org/10.1046/j.1525-1314.1999.00208.x

Otamendi JE, Castelarini PA, Fagiano M, Demichelis A, Tibaldi AM (2004) Cambrian to Devonian geologic evolution of the Sierra de Comechingones, eastern Sierras Pampeanas: evidence for the development and exhumation of continental crust on the protopacific margin of Gondwana. Gondwana Res 7(4):1143-1155. https://doi.org/10.1016/S1342-937X(05)71090-X

Otamendi JE, Ducea MN, Bergantz GW (2012) Geological, petrological and geochemical evidence for progressive construction of an arc crustal section, Sierra de Valle Fértil, Famatinian Arc, Argentina. J Petrol 53(4):761-800. https://doi.org/10.1093/petro logy/egr079

Otamendi JE, Ducea MN, Cristofolini EA, Tibaldi AM, Camilletti GC, Bergantz GW (2017) U-Pb ages and Hf isotope compositions of zircons in plutonic rocks from the central Famatinian arc, Argentina. J South Am Earth Sci 76:412-426. https://doi.org/10.1016/j. jsames.2017.04.005

Palin RM, White RW, Green ECR, Diener JFA, Powell R, Holland TJB (2016) High grade metamorphism and partial melting of basic and intermediate rocks. J Metamorph Geol 34:871-892. https:// doi.org/10.1111/jmg.12212

Pankhurst RJ, Rapela CW (1998) The proto-Andean margin of Gondwana: an introduction. In: Pankhurst RJ, Rapela CW (eds) The Proto-Andean Margin of Gondwana. Geological Society (London), vol 142, pp 1-9. https://doi.org/10.1144/gsl. sp.1998.142.01.01

Pankhurst RJ, Rapela CW, Fanning CM (2000) Age and origin of coeval TTG, I-S-type granites in the Famatinian belt of NW Argentina. Trans R Soc Edinb Earth Sci 91:151-168. https:// doi.org/10.1017/s0263593300007343

Pankhurst RJ, Rapela CW, Saavedra J, Baldo E, Dahlquist J, Pascua I, Fanning CM (1998) The Famatinian magmatic arc in the central Sierras Pampeanas: an Early to Mid-Ordovician continental arc on the Gondwana margin. In: Pankhurst RJ, Rapela CW (eds) The Proto-Andean Margin of Gondwana. Geological Society (London), vol 142, pp 343-367. https://doi.org/10.1144/gsl. sp.1998.142.01.17

Pascua I (1998) Las rocas ígneas y metamórficas de la Sierra de los Llanos, La Rioja, Argentina: evolución famatiniana de un sector del basamento pre-mesozoico Andino. Dissertation, University of Salamanca, Spain

Philpotts JA, Schnetzler CC (1970) Phenocryst-matrix partition coefficients for $\mathrm{K}, \mathrm{Rb}, \mathrm{Sr}$ and $\mathrm{Ba}$, with applications to anorthosite and basalt genesis. Geochim Cosmochim Acta 34(3):307-322. https ://doi.org/10.1016/0016-7037(70)90108-0

Pinotti LP, Coniglio JE, Esparza AM, D’Eramo FJ, Llambías EJ (2002) Nearly circular plutons emplaced by stoping at shallow crustal levels, Cerro Áspero batholith, Sierras Pampeanas de Córdoba, Argentina. J South Am Earth Sci 15:251-265. https://doi. org/10.1016/S0895-9811(02)00033-0

Pinotti LP, Tubía JM, D’Eramo FJ, Vegas N, Sato AM, Coniglio JE, Aranguren A (2006) Structural interplay between plutons during the construction of a batholith (Cerro Áspero batholith, Sierras de Córdoba, Argentina). J Struct Geol 28(5):834-849. https:// doi.org/10.1016/j.jsg.2006.02.004

Pinotti LP, Coniglio JE, D'Eramo FJ, Demartis M, Otamendi JE, Fagiano MR, Zambroni NE (2014) El magmatismo devónico: geología del batolito de Cerro Áspero. In: Martino RD, Guereschi AB (eds) Relatorio del XIX Congreso Geológico Argentino: Geología y Recursos Naturales de la provincia de Córdoba. Asociación Geológica Argentina, Part I, pp 255-276

Pinotti LP, D’Eramo FJ, Weinberg RF, Demartis M, Tubía Martínez JM, Coniglio JE, Radice S, Maffini MN, Aragón E (2016) Contrasting magmatic structures between small plutons and batholiths emplaced at shallow crustal level (Sierras de Córdoba, Argentina). J Struct Geol 92:46-58. https://doi.org/10.1016/j. jsg.2016.09.009

Radice S, Arangue J, Fagiano M, Pinotti LP, Cristofolini E (2015) Microfábricas de deformación del basamento metamórfico, sector centro-oriental de la Sierra de Comechingones, Córdoba. Rev de la Asociación Geol Argent 72(2):157-166

Radice S, Sola AM, Maffini MN, D'Eramo FJ, Weinberg RF, Pinotti LP, Demartis M, Coniglio JE, Boffadossi MA, Muratori ME (2020) Constraining the timing and evolution of a long-lived tectonic boundary: an example from the Early Paleozoic Argentina. J South Am Earth Sci. https://doi.org/10.1016/j.jsame s.2020.102892

Rapela CW, Pankhurst RJ, Casquet C, Baldo E, Saavedra J, Galindo C, Fanning CM (1998a) The Pampean Orogeny of the southern proto-Andes: evidence for Cambrian continental collision in the Sierras de Cordoba. In: Pankhurst RJ, Rapela CW (eds) The Proto-Andean Margin of Gondwana. Geological Society (London), Special Publication, vol 142, pp 181-217

Rapela CW, Pankhurst RJ, Casquet C, Baldo E, Saavedra J, Galindo C (1998b) Early evolution of the proto-Andean margin of South America. Geology 26(8):707-710. https://doi.org/10.1130/00917613(1998)026\%3c0707:EEOTPA\%3e2.3.CO;2

Rapela CW, Pankhurst RJ, Casquet C, Dahlquist JA, Fanning CM, Baldo EG, Galindo C, Alasino PH, Ramacciotti CO, Verdecchia SO, Murra JA, Basei MAS (2018) A review of the Famatinian Ordovician magmatism in southern South America: evidence of lithosphere reworking and continental subduction in the early proto-Andean margin of Gondwana. Earth Sci Rev 187:259-285. https://doi.org/10.1016/j.earscirev.2018.10.006

Rapp RP, Watson EB, Miller CF (1991) Partial melting of amphibolite eclogite and the origin of Archean trondhjemites and tonalites. In: Haapala I, Condie KC (eds) Precambrian Granitoids-petrogenesis, geochemistry and metallogeny. Precambrian Research, vol 51, pp 1-25. https://doi.org/10.1016/0301-9268(91)90092-o

Rapp RP, Watson EB (1995) Dehydration melting of metabasalt at 8-32 kbar: implications for continental growth and crust-mantle recycling. J Petrol 36:891-931. https://doi.org/10.1093/petro $\log y / 36.4 .891$

Reichardt H, Weinberg RF (2012) The dike swarm of the Karakoram shear zone, Ladakh, NW India: Linking granite source 
to batholith. Geol Soc Am Bull 124(1-2):89-103. https://doi. org/10.1130/b30394.1

Reichardt H, Weinberg RF, Andersson UB, Fanning CM (2010) Hybridization of granitic magmas in the source: the origin of the Karakoram Batholith, Ladakh, NW India. Lithos 116:249-272. https://doi.org/10.1016/j.lithos.2009.11.013

Rushmer T (1991) Partial melting of two amphibolites: contrasting experimental results under fluid-absent conditions. Contrib Miner Petrol 107(1):41-59. https://doi.org/10.1007/bf00311184

Schnetzler C, Philpotts JA (1970) Partition coefficients of rare-earth elements between igneous matrix material and rock-forming mineral phenocrysts-II. Geochim Cosmochim Acta 34(3):331-340. https://doi.org/10.1016/0016-7037(70)90110-9

Schwartz JJ, Gromet LP (2004) Provenance of a late Proterozoic-early Cambrian basin, Sierras de Córdoba, Argentina. Precambrian Res 129(1-2):1-21. https://doi.org/10.1016/j.precamres.2003.08.011

Semenov I, Weinberg RF (2017) A major mid-crustal decollement of the Paleozoic convergent margin of western Gondwana: the Guacha Corral shear zone, Argentina. J Struct Geol 103:75-99. https ://doi.org/10.1016/j.jsg.2017.08.009

Semenov I, Weinberg RF, Taylor RJM, Jourdan F (2019) Prolonged Movement on a $>10-\mathrm{km}$-Wide Thrust During Early Paleozoic Orogens in the Gondwana Margin of NW Argentina. Tectonics 38(8):3210-3236. https://doi.org/10.1029/2018tc005417

Sen C, Dunn T (1994) Dehydration melting of a basaltic composition amphibolite at 1.5 and $2.0 \mathrm{GPa}$ : implications for the origin of adakites. Contrib Miner Petrol 117(4):394-409. https://doi. org/10.1007/bf00307273

Sims J, Ireland TR, Camacho A, Lyons P, Pieters PE, Skirrow R, Stuart-Smith PG, Miró R (1998) U-Pb, Th-Pb, and Ar-Ar geochronology from the Southern Sierras Pampeanas, Argentina: implications for the Paleozoic tectonic evolution of the western Gondwana margin. In: Pankhurst RJ, Rapela CW (eds) The Proto-Andean Margin of Gondwana, vol 142. Geological Society (London), pp 259-281. https://doi.org/10.1144/GSL. SP.1998.142.01.13

Steenken A, Wemmer K, Martino RD, López de Luchi MG, Guereschi A, Siegesmund S (2010) Post-Pampean cooling and the uplift of the Sierras Pampeanas in the west of Córdoba (Central Argentina). Neues Jahrbuch für Geologie und Paläontologie Abhandlungen 256(2):235-255. https://doi. org/10.1127/0077-7749/2010/0094

Steenken A, López de Luchi MG, Martínez Dopico C, Drobe M, Wemmer K, Siegesmund S (2011) The Neoproterozoic-early Paleozoic metamorphic and magmatic evolution of the Eastern Sierras Pampeanas: an overview. Int J Earth Sci 100(2-3):465-488. https ://doi.org/10.1007/s00531-010-0624-0

Stepanov AS, Hermann J, Rubatto D, Rapp RP (2012) Experimental study of monazite/melt partitioning with implications for the REE, Th and U geochemistry of crustal rocks. Chem Geol 300301:200-220. https://doi.org/10.1016/j.chemgeo.2012.01.007

Stuart-Smith PG, Camacho A, Sims JP, Skirrow RG, Lyons P, Pieters PE, Black L, Miró R (1999) Uranium-lead dating of felsic magmatic cycles in the southern Sierras Pampeanas, Argentina: Implications for the tectonic development of the protoAndean Gondwana margin. In: Ramos VA, Keppie JD (eds) Laurentia-Gondwana before Pangea. Geological Society of America Special Paper, vol 336, pp 87-114. https://doi. org/10.1130/0-8137-2336-1.87

Suzaño N, Becchio R, Sola A, Ortiz A, Nieves A, Quiroga M, Fuentes $G$ (2017) The role of magma mixing in the evolution of the Early Paleozoic calc-alkaline granitoid suites. Eastern magmatic belt, Puna, NW Argentina. J S Am Earth Sci 76:25-46. https://doi. org/10.1016/j.jsames.2017.02.008
Tepper JH, Nelson BK, Bergantz GW, Irving AJ (1993) Petrology of the Chilliwack batholith, North Cascades, Washington: generation of calc-alkaline granitoids by melting of mafic lower crust with variable water fugacity. Contrib Miner Petrol 113(3):333351. https://doi.org/10.1007/bf00286926

Troll VR, Chadwick JP, Ellam RM, Mc Donnell S, Emeleus CH, Meighan IG (2005) Sr and Nd isotope evidence for successive crustal contamination of Slieve Gullion ring-dyke magmas, Co. Armagh Ireland. Geol Mag 142(6):659-668. https://doi. org/10.1017/s0016756805001068

Walker BA, Bergantz GW, Otamendi JE, Ducea MN, Cristofolini EA (2015) A MASH Zone Revealed: the Mafic Complex of the Sierra Valle Fértil. J Petrol 56(9):1863-1896. https://doi. org/10.1093/petrology/egv057

Wang Y, He H, Cawood PA, Srithai B, Feng Q, Fan W, Zhang Y, Qian $\mathrm{X}$ (2016) Geochronological, elemental and Sr-Nd-Hf-O isotopic constraints on the petrogenesis of the Triassic post-collisional granitic rocks in NW Thailand and its Paleotethyan implications. Lithos 266-267:264-286. https://doi.org/10.1016/j.litho s.2016.09.012

Weinberg RF, Becchio R, Farias P, Suzaño N, Sola A (2018) Early Paleozoic accretionary orogenies in NW Argentina: Growth of West Gondwana. Earth Sci Rev 187:219-247. https://doi. org/10.1016/j.earscirev.2018.10.001

Weinberg RF, Hasalová P (2015) Water-fluxed melting of the continental crust: a review. Lithos 212-215:158-188. https://doi. org/10.1016/j.lithos.2014.08.021

Weinberg RF, Mark G (2008) Magma migration, folding, and disaggregation of migmatites in the Karakoram shear zone, Ladakh, NW India. Geol Soc Am Bull 120:994-1009. https://doi.org/10.1130/ B26227.1

Whitmeyer SJ, Simpson C (2003) High strain-rate deformation fabrics characterize a kilometers-thick Paleozoic fault zone in the Eastern Sierras Pampeanas, central Argentina. J Struct Geol 25:909-922. https://doi.org/10.1016/S0191-8141(02)00118-9

Whitney DL, Evans BW (2010) Abbreviations for names of rock-forming minerals. Am Miner 95(1):185-187. https://doi.org/10.2138/ am.2010.3371

Winther KT (1996) An experimentally based model for the origin of tonalitic and trondhjemitic melts. Chem Geol 127(1-3):43-59. https://doi.org/10.1016/0009-2541(95)00087-9

Wolf MB, Wyllie PJ (1991) Dehydration-melting of solid amphibolite at $10 \mathrm{kbar}$ : textural development, liquid interconnectivity and applications to the segregation of magmas. Mineral Petrol 44:151-179. https://doi.org/10.1007/bf01166961

Wolf MB, Wyllie PJ (1994) Dehydration-melting of amphibolite at 10 kbar: The effects of temperature and time. Contrib Miner Petrol 115:369-383. https://doi.org/10.1007/bf00320972

Yakymchuk C, Zhao W, Wan Y, Lin S, Longstaffe FJ (2019) Fluidpresent anatexis of Neoarchean tonalite and amphibolite in the Western Shandong Province. Lithos 326-327:110-124. https:// doi.org/10.1016/j.lithos.2018.12.014

Zartman RE, Doe BR (1981) Plumbotectonics-the model. Tectonophysics 75:135-162. https://doi.org/10.1016/00401951(81)90213-4

Zeng L, Asimow PD, Saleeby JB (2005a) Coupling of anatectic reactions and dissolution of accessory phases and the $\mathrm{Sr}$ and $\mathrm{Nd}$ isotope systematics of anatectic melts from a metasedimentary source. Geochim Cosmochim Acta 69(14):3671-3682. https:// doi.org/10.1016/j.gca.2005.02.035

Zeng L, Saleeby JB, Asimow P (2005b) Nd isotope disequilibrium during crustal anatexis: a record from the Goat Ranch migmatite complex, southern Sierra Nevada batholith. Calif Geol 33(1):53. https://doi.org/10.1130/g20831.1 
Zhang C, Holtz F, Koepke J, Wolff PE, Ma C, Bédard JH (2013) Constraints from experimental melting of amphibolite on the depth of formation of garnet-rich restites, and implications for models of Early Archean crustal growth. Precambr Res 231:206-217. https://doi.org/10.1016/j.precamres.2013.03.004
Zhu XK, O’Nions RK (1999) Monazite chemical composition: some implications for monazite geochronology. Contrib Mineral Petrol 137(4):351-363. https://doi.org/10.1007/s004100050555 